\title{
Filip Zubčević i Josip Vasiljević - svjetovni svećenici iz Hercegovine školovani u Zagrebu
}

RudOLF BARIŠIĆ

Hrvatski studiji Sveučilišta u Zagrebu Borongajska cesta 83d

HR - 10000 Zagreb

E-pošta: rbarisic@hrstud.hr

\author{
UDK: 262.1:378] \\ 929 Zubčević $F$ \\ 929 Vasiljević J. \\ Izvorni znanstveni rad \\ Primljeno: 14. studenoga 2017. \\ Prihvaćeno: 30. svibnja 2018.
}

\section{Sažetak}

Sredstvima zaklade, koju je 1785. osnovao habsburški vladar Josip II., u periodu do 1847. financirani su boravak i školovanje više od 250 klerika Franjevačke provincije Bosne Srebrene. Međutim, prvotnom nakanom ove zaklade bilo je stvaranje svjetovnoga svećenstva iz redova mladića s bosansko-hercegovačkoga prostora kao preduvjet za uvođenje redovite dijecezanske strukture. $\mathrm{U}$ tu je svrhu u Zagreb poslano 12 mladića, no njihov boravak ondje je završio fijaskom. Habsburškim neuspjehom u Dubičkom ratu (1788. - 1791.) spomenuti planovi su postali neizvedivi i klerici su prepušteni svojoj sudbini. Velik dio ih je postupno napustio stipendiju i tek ih je manji broj dogurao do kraja školovanja. Među njima su se nalazila i dvojica Hercegovaca: Josip Vasiljević i Filip Zubčević. U radu se donosi prikaz njihova školovanja kroza sve nastavne razine te okolnosti u kojima se ono odvijalo. Vasiljević je kasnije bio pastoralno aktivan u tadašnjoj Bosansko-srijemskoj biskupiji sa sjedištem u Đakovu. Zubčevićeva sudbina nakon školovanja nije poznata. Postoje indicije da se vratio u osmansku Bosnu i ondje pastoralno djelovao, ali ih se za sada može iznijeti samo kao pretpostavku.

Ključne riječi: Filip Zubčević; Josip Vasiljević; Kraljevska akademija; biskupski licej; Zagreb; zaklada Josipa II. 


\section{Uvod}

Jednu od upadliivijih karakteristika crkvene povijesti bosansko-hercegovačkoga prostora predstavlja dugotrajan izostanak usustavljene i organizirane dijecezanske strukture. Ovakva je situacija prisutna od srednjega vijeka pa sve do 1881 . i nije uvijek jednostavno ocjenjivati koliki je i kakav utjecaj imala na ukupnu povijest promatranoga područja. Kroz povijest je poznato više pokušaja da se spomenuto stanje promijeni, a među njima je najveći odjek imalo osnivanje Apostolskoga vikarijata u Bosni imenovanjem fra Mate Delivića naslovnim bolinskim biskupom i apostolskim vikarom. ${ }^{1}$ Iako je apostolski vikarijat nastao kao svojevrstan vid kasnih posttridentskih nastojanja Rimske kurije, njegovo je djelovanje u prvih pedesetak godina proteklo bez izraženijih upletanja izvana. Kurija je bila zadovoljna situacijom u kojoj je u Bosni ${ }^{2}$ stalno boravio biskup koji je s jedne strane mogao dijeliti sve potrebne sakramente, a s druge obavljati redovite vizitacije i o tome slati izvješća u Rim. Na djelatnost apostolskih vikara utjecali su brojni, obično nepovoljni, čimbenici. U materijalnom pogledu su u potpunosti bili upućeni na pomoć sa strane, kako na novčanu pripomoć koju su im slali Rim i povremeno Beč, tako i na Bosnu Srebrenu koja im je omogućavala smještaj u nekome od svojih samostana. Ovisnost o bosanskim franjevcima bila je izražena i po pravnom pitanju jer osmanske vlasti nisu priznavale apostolskoga vi-

1 Okolnosti osnivanja vikarijata Srećko M. DžAJA, Katolici u Bosni i zapadnoj Hercegovini na prijelazu iz 18. u 19. stoljeće - Doba fra Grge Ilijića Varešanina (1783-1813), Kršćanska sadašnjost, Zagreb, 1971., str. 104-105; JulijAn JELENIĆ, Izvori za kulturnu povijest bosanskih franjevaca, Zemaljska štamparija, Sarajevo, 1913., str. 97 donosi citat u kojemu su navedene njegove granice: "Amplitudo longitudinis, et latitudinis Vicariatus Apostolici Bosnensis, non potest juste metiri, nec describi (...). Communes tamen termini sunt = Ex parte Sclavoniae, et Confinio Imperii flumen Savus, nobis Sava. Ex parte Serviae (...) flumen Drina. Ex parte Dalmatiae mons Prologh (...). Ex parte Croatiae Mons dictus Plissivicza."

2 Pojmovi "Bosna" i "bosanski" koriste se u kontekstu onovremenih administrativnih granica koje su bile ponešto drugačije nego li suvremene granice Bosne i Hercegovine. Bosna Srebrena i Apostolski vikarijat u Bosni nisu obuhvaćali prostor Trebinjsko-mrkanske biskupije, dok su u Bosnu kao administrativnu jedinicu Osmanlijskoga Carstva bila uključena i neka područja koja se danas nalaze u Crnoj Gori i Srbiji. Stoga, primjerice, pojam "bosanski klerik" valja promatrati u kontekstu pripadnosti Bosni Srebrenoj, ako je dotični bio franjevac, odnosno apostolskom vikarijatu, čak i ako je pojedinac bio rodom iz Hercegovine. 
kara kao pravni subjekt. Konačno, ova je ovisnost bila najupadljivija u pitanju župa, tj. njihova popunjavanja i upravljanja jer su ponovo bosanski franjevci činili jedini kadar iz kojega su se "novačili" potencijalni župnici. ${ }^{3}$

Poučena ranijim prijeporima i općenito otporom koji su franjevci pokazivali prema ikakvoj aplikaciji biskupskoga nadleštva, Sveta je Stolica u imenovanju apostolskim vikarom nekog od bosanskih franjevaca vjerojatno davala diplomatski ustupak koji je ipak imao svoje granice. U franjevačkoj se tradiciji razvilo tumačenje kako je Bosna Srebrena imala pravo predlaganja četiriju kandidata iz svojih redova od kojih bi onda Rim izabirao i potvrđivao jednoga. Ova je teza ipak neodrživa, a uostalom zanijekala ju je i sama praksa. Ne postoje potvrde da je izbor ikada tekao na opisan način. U samoj Bosni Srebrenoj prilikom izbora novoga apostolskog vikara, dakako, nije nedostajalo niti ideja tko bi bio poželjan kandidat, kao niti pojedinačnih ambicija i samopreporučivanja u tom smislu, ali na konačan su izbor utjecaj mogli vršiti i drugi. Vjerojatno je činjenica da su svi apostolski vikari do Augustina Botoša Okića izabrani bez protivljenja Bosne Srebrene pomogla kasnijem razvijanju ideje o isključivom pravu franjevaca na predlaganje vlastitih kandidata. Ipak, činjenica je kako je Okić izabran bez privole Bosne Srebrene, isključivom habsburškom podrškom. Njegov mandat, koji se često zbog ratnih događanja i njegova zdravstvenoga stanja ocjenjuje kao nesadržajan, uveo je još jednu novu praksu koja će potrajati idućih pola stoljeća: zbog bolesti zatražio je da mu se imenuje pomoćnik pa je na tu službu 1796. godine imenovan Grgo Ilijić Varešanin. Kako je tom prilikom i on dobio naslovnu biskupsku titulaturu, pitanje budućega apostolskog vikara bilo je riješeno već tada. Identičan slučaj, gdje je neki od bosanskih franjevaca još za života apostolskoga vikara, u svojstvu njegova pomoćnika, bio imenovan biskupom i time na neki način postao predodređen i za njegova nasljednika, dogodio se i 1803. godine kada je Augustin Miletić, imenovan Ilijićevim pomoćnikom, stekao i biskupsku titulu. Dvadesetak godina kasnije Rafo Barišić, doduše, nije bio imenovan biskupom, ali je u prednost pred

3 Osim franjevaca, sve do prve polovice 19. st. osobito u Hercegovini te duvanjskom i livanjskom kraju brojni su bili popovi glagoljaši, prisutni i drugdje u Bosni. Apostolski vikari su prema ovim popovima pokazivali određeni zazor i to iz dva razloga. Kao prvo, bili su dosljedni pobornici rimskoga obrednika u bogoslužju, a kao drugo, u glagoljašima su gledali eksponente dalmatinskih biskupa s kojima su imali prijepore oko jurisdikcijskih granica. 
ostalim kandidatima za Miletićeva nasljednika sigurno došao već i samim time što je bio imenovan njegovim provikarom.

Iako su i apostolski vikari redom bili franjevci Bosne Srebrene, to ipak nije sprječavalo neke među njima da postave pitanje jurisdikcijskih ovlasti što je posljedično moglo izazvati razmirice pa čak i otvorene sukobe. Premda je najizraženiji lom nastao u prvoj polovici 19. st. u vidu znamenite "Barišićeve afere", nesuglasice su tinjale i prerastale u otvorene sukobe već i ranije. Uz ime Grge Ilijića vežu se čak tri "afere", a svima je zajedničko da su bile vezane za pitanje nadležnosti oko popunjavanja i upravljanja župama. ${ }^{4}$ Ilijić je prvenstvo apostolskoga vikara nastojao pokazati uzdizanjem nekih kapelanija na rang župa bez prethodnih konzultacija s Bosnom Srebrenom. U tome je na kraju uspio, ali je svejedno i dalje bio ovisan o franjevcima u pogledu kadrova za župničku službu.

U ovome se kontekstu u potpunosti može razumjeti i razvoj onoga što predstavlja najveću ostavštinu Okićeva vršenja službe apostolskoga vikara - zaklade koju je na njegovu molbu i nagovor osnovao Josip II., a čijim se sredstvima ubuduće trebalo financirati školovanje bosanskih klerika i njihov boravak u Habsburškoj Monarhiji. ${ }^{5} \mathrm{Za}-$ klada je nastala u sklopu Josipovih priprema za preotimanje Bosne Osmanskome Carstvu. Ostvarenjem tih planova stvorili bi se i preduvjeti za uvođenje ${ }^{6}$ redovite dijecezanske strukture. Prvotne ideje

4 Afere detaljno opisuje S. M. DžaJa, Katolici u Bosni i zapadnoj Hercegovini, str. 189-223.

5 O okolnostima osnivanja zaklade vidi opširnije: Rudolf BARIšıć, "Početak školovanja bosanskih klerika na učilištima u Habsburškoj Monarhiji", u: PAvao Knezović - Marko Jerković (ur.), Zbornik o Mati Zoričiću: Zbornik radova sa znanstvenog skupa, Knjižnica Tihi pregaoci - Hrvatski studiji Sveučilišta u Zagrebu, Zagreb, 2012., str. 179-201; RuDOLF BARIšić, "Školovanje Jure (fra Petra) Kordića", u Hercegovina: Časopis za kulturno i povijesno naslijeđe, 26 (1), Mostar, 2015., str. 165-185, osobito 167-170.

6 Termin se koristi kao koliko-toliko neutralna odrednica jer do danas ne postoji slaganje radi li se o "obnavljanju" nekad postojećih dijeceza ili "osnivanju" sasvim novih, pri čemu je potonje tumačenje ono koje zastupa franjevačka tradicija. Zaobilazeći ovom prilikom prosudbe oko ovoga iznimno složenoga crkveno-pravnoga pitanja i historiografskoga problema, ukazivanjem na njegovu aktualnost i danas jasno se može naznačiti koliko je snažna povijesna specifičnost bosansko-hercegovačkih prilika u pogledu odnosa između dijecezanske i redovničke (franjevačke) hijerarhije. O tome više u: SREćko M. DžAJA, Konfesionalnost i nacionalnost Bosne i Hercegovine - predemancipacijsko razdoblje 1463.-1804., ZIRAL, Mostar - Sarajevo, 1999., str. 194-201. 
i naumi habsburške strane sa zakladom jasno su naznačile u kojem bi smjeru išao taj proces. U jednoj od uputa koje je Okić dobio pred njega je stavljen zadatak prikupljanja kandidata bez redovničkoga zavjeta, o čemu će biti više riječi kasnije u tekstu. Time je jasno izražena nakana da dijecezanska struktura bude utemeljena na domaćim kadrovima i neovisna o Bosni Srebrenoj. Okićeva uloga i stavovi u tome ostaju pomalo nejasni. Kako će biti prikazano, sa svoje je strane učinio sve što je mogao da udovolji spomenutom zahtjevu, ali nemoguće je utvrditi je li to učinio zbog toga da sredstva zaklade ne ostanu neiskorištena ili i zbog toga što se nadao sam postati pravim biskupom nakon očekivanoga pripajanja Bosne Monarhiji.

U svakom slučaju, njegovim zalaganjem u Zagrebu se tijekom 1787. godine postupno okupila skupina od 11 mladića iz osmanlijske Bosne, među kojima i nekoliko Hercegovaca. Jedan od njih, Jure Kordić se po završetku školovanja vratio u Kreševo i ondje stupio u franjevački red uzevši ime fra Petar te je kasnije, između ostaloga, vršio i službu bosanskoga provincijala. ${ }^{7}$ Sudbinom druge dvojice, a koji su također postali svećenicima, historiografija se do sada nije bavila. $\mathrm{Na}$ osnovi trenutačno raspoložive arhivske građe može se rasvijetliti period njihova školovanja koji su proveli u Zagrebu pripremajući se biti temeljem plana koji se ostvario tek cijelo stoljeće kasnije. Cilj je ovoga rada prikazati okolnosti i tijek njihova školovanja te daljnju sudbinu neposredno po njegovu dovršetku.

\section{Porijeklo klerikâ}

Oba klerika o kojima je ovdje riječ, Filip Zubčević i Josip Vasiljević, prvi se put spominju u financijskom izvješću koje je Kraljevskom ugarskom namjesničkom vijeću (dalje KUNV) podnio Kajetan Auker, gvardijan zagrebačkoga samostana Franjevačke provincije sv. Ladislava. ${ }^{8}$ Prema njemu, obojica su u zagrebački samostan stigli 1. rujna 1787. u najvećoj grupi sekularnih klerika, a zajedno s njima doputovali su i Ivan Alović, Jure Kordić, Stjepan Vidović, Anto Nikolić, Pavao Nikolić ${ }^{9}$ i Pavao Botoš Okić. Kako je Auker nastojao dobiti

7 O njemu opširnije u: R. BARIšić, nav. dj., str. 166-167.

8 Nadbiskupijski arhiv u Zagrebu (dalje: NAZ), Spisi Nadbiskupskog duhovnog stola (Officium dioecesanum) [dalje: NDS (OD)], 845/1788. Prvi broj predstavlja oznaku protokolarnoga unosa, a drugi godište.

9 Obojica Nikolića bili su rođeni u Kreševu, ali je precizan rodbinski odnos za sada nemoguće utvrditi. Pouzdano je jedino da nisu bili braća. 
povrat troškova za uzdržavanje klerika koje je podmirio sredstvima iz samostanske blagajne, $u$ izvješću se nalazi detaljan popis različitih stavki. Na nekoliko se mjesta nalazi i Zubčevićevo ime. Tako su 9. travnja 1788. za njega nabavljene sandale, 28. lipnja iste godine i cipele, a već 13. srpnja sandale su morale biti odnesene na popravak. U kontekstu troškova oko održavanja i popravka obuće dva puta se spominje i Vasiljevićevo ime. Osim toga, navedeni su i neki skupni troškovi, poput nabavke papira ili svijeća, kao i lijekova, ali nije navedeno koji su klerici i od čega bolovali. Što se pak tiče troškova za živežne namirnice, Auker je naveo kako je za cijelu grupu u kojoj su pristigli Zubčević i Vasiljević potrošio 11 forinti po kleriku. Prije nego li se nastavi prikaz njihova boravka u Zagrebu te raščlamba školovanja, valja nešto reći o njihovu porijeklu, odnosno okolnostima u kojima su uopće došli u Zagreb.

Kako je već rečeno, školska izvješća i pojedini spisi Nadbiskupskoga duhovnog stola u Zagrebu trenutačno predstavljaju jedine izvore o njima. Niti u jednome od njih ne nalazi se točan datum rođenja. Izvješća Kraljevske gimnazije sastavljana su dva puta godišnje, za svako polugodište po jednom, te obično obuhvaćaju dva dijela. Prvi je poimeničan popis učenika u kojemu se kroz više rubrika donose najvažniji biografski podatci (ime i prezime, vjeroispovijest, mjesto rođenja, dob, uzdržavatelji) te oni o školovanju (opći uspjeh, vladanje, određene druge opaske). Drugi se obično naziva Classificatio i u njemu su učenici poredani po uspjehu od najboljeg do najlošijeg obično kroz tzv. redove (classis), najčešće dva (prvi i drugi), ali se povremeno javljaju i treći za posebno neuspješne učenike, dok se najbolje označavalo atribucijom eminens. Tijekom dviju nižih razina (gramatike i humaniora) sastavljana su samo dva skupna, dok su tijekom studija filozofije kao više razine, podnošena za svaki pojedini predmet. Ovom nas prilikom najviše zanimaju podatci o dobi i mjestu rođenja.

U slučaju bosanskih klerika oni su obično veoma neujednačeni, često i naizgled kontradiktorni. Dok se mjesto rođenja još koliko-toliko može precizno utvrditi, godine rođenja moguće je postaviti samo okvirno. Problem proizlazi već i iz okolnosti da nije poznato kojom su se metodom pojedini sastavljači izvješća koristili prilikom prikupljanja podataka. Kako to izgleda u ova dva slučaja?

Zubčevićevo se ime javlja u ukupno 22 izvješća. Kao mjesto rođenja navedeni su Brotnjo (3 puta) i Mostar (10 puta). U ostalim slučajevima Zubčević je ubilježen samo kao "Bosanac" (Bosnensis), ponekad 
uz nekakvu oznaku socijalnoga statusa (npr. plebejus). Ovo "bosanstvo" treba, kako je već rečeno, promatrati kroz prizmu administrativne pripadnosti bilo Brotnja, bilo Mostara. Kod drugih klerika koji su potjecali iz Hercegovine ponekad je jasno naglašena regionalna pripadnost. Kao najslikovitiji primjer može poslužiti lokacija sljedećega sadržaja: "Oppidum Herzegovina in Bassatu Travnikensi" uz ime Josipa Vasiljevića. ${ }^{10}$

Kako je vjerojatno sam Zubčević bio glavnim informatorom za podatke o sebi, otvara se pitanje zbog čega je davao različite lokacije. U oči upada i još jedna nekonzistentnost. Brotnjo se kao mjesto rođenja navodi kada je Zubčević tijekom šk. god. 1788./1789. pohađao prvi razred gramatike. Dvije godine kasnije, kada se nalazio u trećem razredu, kao mjesto rođenja navodi Mostar. U vrijeme šk. god. 1793./1794. Zubčeviću je, sada već kao polazniku prve godine filozofije, kao mjesto rođenja ponovo upisano Brotnjo, ali je tijekom idućih godina ova rubrika redovito popunjavana Mostarom. Premda bi se očekivalo da bi češće spominjani Mostar trebao imati prednost pred Brotnjom, nije isključeno da je Zubčević na neki način bio povezan $s$ obje lokacije. Prilikom popunjavanja rubrike o podrijetlu nikada nije izrijekom navedeno da se radi o mjestu rođenja, nego se moglo raditi i o mjestu prebivališta ili posljednjem boravištu prije prelaska u Zagreb. Ovdje nam ponovo može pomoći usporedba s Vasiljevićem kod kojega je spomenuta rubrika još šarolikije popunjavana. Osim već spomenutoga "grada Hercegovine u Travničkom pašaluku", izvješća, njih 16 ukupno, Vasiljevića smještaju i u Brotnjo, Sarajevo, Kreševo i Međugorje te jednom prilikom na lokaciju koju je teže preciznije odrediti, a možda se radi o Rasnu. ${ }^{11}$ Naizgled zbunjujući, ovaj nam popis omogućava bolje razumijevanje načina na koji su izvješća sastavljana, ali i Vasiljevićeve biografije. Ukratko, opravdano je pretpostaviti da je rođen u Međugorju koje je pripadalo župi Brotnjo. U Kreševu je pak proveo neko vrijeme očito se pripremajući stupiti u franjevački red. Što se tiče Sarajeva, moguće je da mu se obitelj, ili barem majka kao udovica, u nekom trenutku preselila onamo. Je-

10 Usp. Državni arhiv u Zagrebu, I. Klasična gimnazija u Zagrebu, 5. Dokumentacija o učenicima (dalje: HR-DAZG-102), kut. 25624, br. 7. Informatio de philosophis primi anni ex Philosophia rationali et Historia philosophiae pro primo semestri anni 1796. Kako će se građa pohranjena u Državnom arhivu u Zagrebu opširno citirati kada bude govora o samom procesu školovanja dvojice klerika, radi preglednosti teksta ovom je prilikom ispuštena.

11 U izvorniku je ovo mjesto prilično nečitko: Carolasno. 
dinim nepoznatim detaljem ostaje spominjanje Rasna, dakako, ako je uopće riječ o tome mjestu. Prema tome, sličnom analogijom nije nemoguće i da se Zubčevićeva obitelj nekada nakon njegova rođenja preselila iz Brotnja u Mostar.

Ma kako se konfuznima doimali, podatci o prebivalištu ipak nedvojbeno potvrđuju njihovo hercegovačko porijeklo. Godinu rođenja je daleko teže odrediti. Ponovo, u izvješćima se nikada nije navodio precizan datum, nego samo dob klerika. Pri tome nije jasno na koji je način ona podrazumijevana. Primjerice, Zubčević se kao polaznik prvog razreda gramatike nalazio u dobi od 17 godina. Ovo izvješće je podneseno na kraju školske godine. Ukoliko ga se tumači na način da je imao "punih 17 godina", odnosno da je bio rođen najkasnije do kraja rujna, onda bi godinu rođenja valjalo odrediti kao 1772. Ako je, pak, bio "u 17. godini života", odnosno rođen u posljednjem kvartalu godine, onda bi godina rođenja bila 1773 . Na žalost, nema načina kojim bi se moglo utvrditi koje je od opisana dva načela korišteno. Vrlo vjerojatno su različiti sastavljači koristili različitu metodu, no to nije jedina mana. Iz nepoznatog razloga podatci znaju pokazivati kontradikcije čak i kada su prikupljani iste godine. Kada je Zubčević šk. god. 1794./1795. prvi put ponavljao prvu godinu filozofije, u četiri različita izvješća njegova je dob ubilježena tako da je imao ili 21 ili 24 godine, a ove su nekonzistentnosti nastavljene i tijekom šk. god. 1795./1796. kada je navedeno da ima 23, odnosno 25 godina, te šk. god. 1796./1797. kada je imao ili 26 ili 27 godina. Kada se analiziraju podatci u svim izvješćima, vremenski okvir Zubčevićeva rođenja kreće se u rasponu 1770. - 1774., a bit će ga moguće precizirati - dakako, ukoliko su sačuvane - jedino na osnovi matica krštenih. $\mathrm{Na}$ žalost, dok su kod ostalih klerika u nekim prilikama spomenuta i imena roditelja, za Zubčevića znamo da je 1794. imao živu majku, ali ne i njezino ime.

Korištenjem iste metode analize, kod Vasiljevića je raspon godina mogućeg rođenja još i veći i obuhvaća period od 1772. do 1778., premda bi ga, sudeći po učestalosti spominjanja, bilo opravdano suziti na razdoblje 1773. - 1775. Zahvaljujući tome što je kasnije stupio u svećenstvo Bosansko-srijemske biskupije, datum njegova rođenja može se i precizirati jer u šematizmu spomenute biskupije iz 1835 . stoji kako je bio rođen 25. studenog $1773 .{ }^{12}$ Izvori čuvaju i imena nje-

12 Usp. Schematismus venerabilis Cleri dioecesium Bosnensis seu Diakovariensis et Syrmiensis canonice unitarum pro anno a Christo nato MDCCCXXXV, die- 
govih roditelja: Mate ${ }^{13}$ i Veronika. Pri tome je ime oca spomenuto samo jednom, nakon čega je navođena samo majka što upućuje na zaključak da mu je otac najkasnije 1795. preminuo te da je Vasiljević za tu informaciju znao. To ukazuje na postojanje određene komunikacije između klerika i njihovih obitelji, ali nemoguće je zaključivati koliko je ona bila učestala i kojim se kanalima kretala.

\section{Dolazak u Zagreb}

Budući da je osnovnom nakanom zaklade bilo stvaranje pretpostavki za uvođenje redovite dijecezanske strukture oslonjene na domaći kadar, bliski suradnik Josipa II., grof Karoly Pálffy pred apostolskoga vikara Botoša Okića stavio je određene kriterije oko odabira kandidata. ${ }^{14}$ Nisu smjeli imati položene redovničke zavjete, a bilo je preporučljivo da su već pohađali gradivo u razini humaniora, drugim riječima da su dobro vladali latinskim, pa bi ih se na studij filozofije moglo poslati bilo kamo na području Monarhije. Dakako, ispunjavanje oba ova uvjeta Okića je stavilo pred nimalo lagan zadatak. Dok interesenata za svećenički poziv sigurno ne bi nedostajalo, jedini koji su već imali kakvo-takvo obrazovanje nalazili su se u franjevačkim samostanima pripremajući se za stupanje u novicijat.

$\mathrm{U}$ ono vrijeme Bosna Srebrena imala je novicijat u svakom od svoja tri samostana. Mladići zainteresirani pridružiti se franjevačkom redu dolazili bi onamo i najprije ondje neko vrijeme boravili pripremajući se za stupanje u novicijat. Ono se događalo svečanim činom oblačenja habita i dodjeljivanja redovničkoga imena. Nakon godinu dana, tijekom kojih bi samostanska zajednica redovitim glasovanjem davala svoje opaske o svakom pojedinom kandidatu, ukoliko ne bi bilo nika-

rum CCCXLV, Pestini Typis Jos. Beimel, C. R. PRIV. Strigoniensis Typographiae ac unius e Pestanis proprietarii (dalje: Schematismus 1835.), str. 93.

13 HR-DAZG-102, kut. 25622, (šk. god. 1793./1794.) br. 15. Tabella morum ac studiorum iuventutis scholasticae in I. humanitatis classe in Archigymnasio Zagrabiensi primo Semestri an. 1793/4. literis operam navantium. Do kraja šk. god. 1793./1794. u pojedinoj kutiji čuvaju se izvješća za dvije različite školske godine. Kako su brojčane oznake, a često i nazivi pojedinih izvješća identični, prilikom citiranja građe iz toga perioda označena je i školska godina. U latinskom tekstu provedene su intervencije u pogledu osuvremenjivanja interpunkcije i pisanja velikoga i maloga slova dok je zadržana izvorna grafija sastavljača teksta.

14 Usp. J. JeLEnIĆ, Izvori, str. 57. 
kvih zaprjeka, novak je odmah polagao doživotne redovničke zavjete. ${ }^{15}$ Za vrijeme pripreme za novicijat, kao i njegova trajanja, kandidati su bili obvezni pohađati nastavu. Njezinom je svrhom bilo pripremanje budućih klerika za odlazak na neko inozemno učilište na studije filozofije i teologije za čiju organizaciju Bosna Srebrena nije imala uvjeta. Formalno, mladići su u Bosni pohađali gramatiku i humaniora, no u biti ovo se obrazovanje svodilo na opismenjavanje u latinici i bosanici te osnove latinske gramatike, uz neizostavnu vjersku naobrazbu. Čak i takva nastava, skromna opsega, održavana je neredovito. Magistri (meštri) novaka kojima je bilo povjereno ovo pitanje, zbog raznoraznih razloga često su dulje vremena izostajali iz samostana, a također i gvardijani su mladiće iskorištavali za fizičke poslove. Usprkos nastojanjima mnogih provincijala da se ove nepravilnosti dokinu, do početka 19. st. nisu napravljeni neki izraženiji pomaci. ${ }^{16}$ Uza sve manjkavosti, kandidati za franjevaštvo bili su jedinim izvorom u kojemu je Okić mogao potražiti kandidate za slanje u Monarhiju.

Imena mladića koji su boravili u samostanu upisivana su tek nakon stupanja u novicijat u knjige novaka, a sekularni klerici to, u skladu s Pálffyjevim uputama, nisu učinili. Usprkos tome, upravo knjige novaka pružaju snažnu indiciju kako je Okić buduće stipendiste odabrao baš među kandidatima za novicijat. Na Aukerovu popisu (vidi gore) nalazi se ukupno 11 imena. ${ }^{17}$ Među njima se nalazi i Josip Zečevićl $^{18}$ čije ime nalazimo u knjizi novaka fojničkoga samostana. Prema njoj je 14. siječnja 1784. stupio u novicijat, ali je sljedeće godine s još nekolicinom zbog disciplinskih prekršaja bio izbačen. Od svih sekularnih klerika, on je jedini koji je prije odlaska na stipendiju neko vrijeme proveo u novicijatu. ${ }^{19}$ Osim njega, fojničkom distriktu su po

15 Ustroj novicijata vidi: ROBERT Jolić, Novicijat hercegovačkih franjevaca, RECIPE Knj. 3, Hercegovačka franjevačka provincija Uznesenja BDM - Naša ognjišta, Mostar - Tomislavgrad, 2009., str. 12-19. Polaganje vječnih zavjeta znalo je biti odgođeno jedino u slučaju nedostatne dobi. Naime, u 18. st. novak je morao navršiti 16 godina kao minimalnu dob za ovaj čin.

16 O ustroju obrazovanja i nepravilnostima više u: S. M. DžajA, Katolici u Bosni i zapadnoj Hercegovini, str. 136-139.

17 Posljednji, dvanaesti klerik, Luka Marijanović, u Zagreb će doći 1792. nakon završetka Dubičkoga rata, usp. NAZ NDS (OD) 993/1792. Int.

18 Kako je potjecao iz Dobretića, u izvorima je najčešće ubilježen pod prezimenom Dobretić.

19 Jure Kordić i Ivan Alović iz Zagreba će se vratiti u Kreševo 1798. i ondje stupiti u novicijat. Usp. R. BARIšić, nav. dj., str. 181. 
rođenju pripadala još dvojica: Toma Pravdić i Luka Marijanović koji su bili iz livanjskoga kraja. Kada se analiziraju mjesta rođenja preostalih klerika, upadljivo je da dominiraju oni rođeni u Kreševu ili okolici (Alović, P. Botoš Okić, oba Nikolića, Tomić i Vidović), a da su ostali bili Hercegovci (Kordić, Vasiljević i Zubčević). Sva devetorica su pak pripadali kreševskom distriktu.

Da mu je Pálffy pri izboru stipendista postavio samo kriterij nepripadanja franjevcima, Okić bi vjerojatno lako prikupio mladiće zainteresirane za svećenički poziv. Da bi pak zadovoljio drugi kriterij, onaj o humaniornom obrazovanju, morao je posegnuti među kandidate za stupanje u franjevački novicijat. Da je bila riječ o delikatnoj odluci, svjedoči i u prethodnom pasusu provedena analiza porijekla klerika. U oči upada izostanak kandidata iz sutješkoga distrikta, kao i to da su u trenutku kada je Okić prikupljao buduće stipendiste, samo dvojica pripadala fojničkom distriktu. K tome, jedan je bio izbačen iz novicijata, ali upravo to indicira da su i ostali kandidati neko vrijeme proveli u franjevačkim samostanima.

Nadalje, u oči upada i činjenica da u Kreševu između 1784. i 1791. nije zabilježeno niti jedno stupanje u novicijat. ${ }^{20}$ Kako su apostolski vikari obično stolovali u onom samostanu kojemu su prema rođenju pripadali, Okić je svoju rezidenciju smjestio u Kreševo. Samim time jasno je da je ondje imao veće mogućnosti provesti ono što je habsburška strana od njega tražila. Za sada nije moguće utvrditi kakvom je bila reakcija franjevaca, ni kakvim se argumentima poslužio apostolski vikar. Napokon, snažan argument u prilog tezi da su stipendisti barem neko vrijeme proveli u kreševskom samostanu i ondje primili kakvu-takvu poduku iz latinskoga jezika predstavljaju i školska izvješća iz šk. god. 1788./1789. U njima se spominju dvojica Hercegovaca. Kordić je pohađao treći, a Zubčević prvi razred gramatike. ${ }^{21}$ Budući da su ostali sekularni klerici u nastavni proces uključivani postupno tijekom idućih godina, a da ni Zubčević nije pokazao nekakav zavidan uspjeh, jasno je da im predznanje doneseno iz Bosne nije bilo na razini potrebnoj da zadovolji kriterije postav-

20 Usp. R. Jolić, Novicijat, str. 41.

21 Usp. HR-DAZG-102, kut. 25620 (šk. god. 1788./1789.), br. 13. Tabella morum ac studiorum iuventutis in I. schola gramaticali in Archigymnasio Zagrabiensi literis operam dantis, anno 1789. semestri altero i br. 10 Calculus studiosorum III. grammatices classi in Regio Archigymnasio Zagrabiensi operam navantium 1788/9. Uz njih se spominju još šestorica klerika od kojih je točno polovica pripadala Bosni Srebrenoj. 
ljene u Zagrebu. S druge strane, očito su ga imali dovoljno da budu uključeni u nastavni proces, a mogli su ga steći jedino u kreševskom, odnosno fojničkom samostanu. Dok bi se za rođene Kreševljake još mogla iznijeti teza da su u samostanu samo pohađali nastavu, a boravili u roditeljskim kućama, Kordićev i Zubčevićev primjer pokazuje da je takva pretpostavka neodrživa, odnosno da je Okić stipendiste prikupio među kandidatima za novicijat. Na taj način nam je poznat još jedan dio Zubčevićeve i Vasiljevićeve biografije premda, kao i po pitanju rođenja, nije moguće preciznije utvrditi kada su došli u Kreševo, niti koliko su dugo ondje boravili.

\section{3 . Boravak u Zagrebu}

Zubčevićev boravak u Zagrebu potrajao je sve do 1800. godine i kako je već naglašeno predstavlja najbolje dokumentirani dio njegova života. Naravno, mnogi detalji ostaju nepoznati. S jedne se strane nalaze podatci o školovanju u kojima postoji malo praznina, ali ostaju u okvirima suhoparnoga nabrajanja razreda i predmeta koje je pohađao, odnosno uspjeha koji je ostvarivao. S druge strane, boravak sekularnih klerika u Zagrebu bio je obilježen brojnim nesuglasicama između njih i franjevaca Provincije sv. Ladislava u čijem su zagrebačkom samostanu bili smješteni. Ova razmimoilaženja kulminirat će u oštre sukobe koji su rješavani pred Duhovnim stolom zagrebačke biskupije, te su stoga dobro dokumentirani. Pomnom analizom mogu se otkriti i neki aspekti kleričke svakodnevice mimo nastave, no kako će stipendisti kao posljedicu tih sukoba postupno napustiti samostan i potražiti privatan smještaj, taj dio njihova života ostaje potpuno nepoznat.

Sukobi između bosanskih klerika i njihovih zagrebačkih domaćina izbili su vrlo brzo po dolasku klerika u Zagreb. Njihovim povodom bila je nedisciplina klerika s jedne, odnosno nevoljkost zagrebačkih franjevaca da ih prime s druge strane, a uzroci su bili kudikamo dublji. Kao što je ideja da se u osmanlijskoj Bosni stvori dijecezansko svećenstvo svoj korijen imala u politici crkvenoga jozefinizma, isti je skup ideja utjecao i na redovničke zajednice u samoj Monarhiji, pa tako i u Hrvatskoj. Premda jozefinizam prema franjevcima nije bio toliko radikalan kao prema nekim drugim crkvenim redovima, primjerice pavlinima, ipak su i oni osjetili neke negativne posljedice Josipovih nastojanja. Neki su samostani bili zatvoreni, ukinuta su samostanska učilišta, a jednako tako bili su doneseni zakoni kojima je dob za stupanje u neki crkveni red pomaknuta na 24 godine s očitim 
ciljem da se obeshrabrivanjem mladih članstvo redovničkih zajednica što više smanji. Ova politika, čiji se začetci nalaze još u vladavini Marije Terezije, do ovdje obrađivanoga razdoblja već je ostavila dubok trag i franjevci nisu blagonaklono gledali na nove intervencije državnoga aparata koji ionako nije vodio računa o njihovim interesima ili željama. Za ilustraciju ovoga odnosa može poslužiti odluka da se klerike smjesti u zagrebački samostan. Pálffy je o tome Okića obavijestio 3. svibnja, a Aukeru je ova odluka priopćena 30. svibnja 1785. dovodeći ga time pred svršen čin, bez prethodnih konzultacija ili uopće traženja pristanka. Također, franjevci i njihovi bosanski gosti su u kolovozu 1788. bili premješteni s Kaptola u napušteni kapucinski samostan, dok se u franjevačkom smjestila vojna bolnica. ${ }^{22}$

Ironično, ali sukobe su izazvala dvojica franjevačkih klerika Bosne Srebrene, povratnici iz Italije Franjo Dobretić i Blaž Kulašević. ${ }^{23} \mathrm{Za}-$ grebački franjevci su u najvećoj mjeri njih dvojicu apostrofirali kao kolovođe cijele grupe, odnosno da su, osobito Dobretić, vršili štetan utjecaj na ostale klerike. Nesuglasice su rezultirale međusobnim optuživanjem pred Duhovnim stolom zagrebačke biskupije u veljači 1789. Tužba usmjerena protiv bosanskih klerika sadrži 12 točaka $s$ nekim konkretnim slučajevima. Zubčevića se poimence spominje samo u jednoj od njih, kao jednoga od nekolicine klerika koji veoma često bez prethodne dozvole napuštaju samostansku zgradu i odaju se skitnji po gradu. Vrlo vjerojatno je i on sudjelovao u nekim skupnim optužbama za podizanje galame, prekomjernom ispijanju vina ili tučnjavi sa samostanskim slugama, no očito se nije u tome pretjerano isticao da bi ga se posebno spomenulo, kao primjerice Vasiljevića koji je apostrofiran kao žešći vinopija s često nelagodnim posljedicama. Zbog neslaganja dijela klerika s Dobretićevim postupcima dolazilo je i do međusobnoga fizičkog razračunavanja, ali izgleda da se Zubčević i Vasiljević nisu u to upuštali.

Ovi su sukobi imali kao posljedicu da su bosanski klerici postupno napuštali samostan i tražili privatni smještaj. U prosincu 1789. skupina klerika, među njima i Zubčević i Vasiljević, obratila se na Duhov-

22 Usp. PašKal Cvekan, Kaptolski franjevci: kulturno povijesni prikaz djelovanja franjevaca kroz 770 godina na Kaptolu u Zagrebu, (vlastita naklada), Zagreb, 1990., str. 69.

23 O cijelom problemu kleričke (ne)discipline više u: R. BARIšić, nav. dj., str. 174177 , gdje su opisani i drugi primjeri. 
ni stol želeći riješiti neke međusobne razmirice. ${ }^{24} \mathrm{U}$ odnosu na prethodno razdoblje, samostan su napustila četvorica klerika, franjevci Dobretić i Kulašević te sekularni klerici P. Botoš Okić i Zečević. Do kolovoza 1790. broj klerika preostalih u samostanu dodatno se smanjio. Prema izvješću koje je Duhovnom stolu podnio samostanski vikar Benvenut Orlić ondje su tada još boravili jedan franjevački klerik i šestorica sekularnih, među njima i Zubčević i Vasiljević. ${ }^{25}$

Zajedno sa Stjepanom Vidovićem, Zubčević se 6. veljače 1792. pismom izravno obratio Maksimilijanu Vrhovcu, žaleći se na postupanje gvardijana. ${ }^{26}$ Uzrok njihova nezadovoljstva bio je dvostruke prirode. $S$ jedne strane, žalili su se na vlastitu materijalnu situaciju, smatrajući da gvardijan cijelo vrijeme njihova boravka u Zagrebu troši dio njihovih stipendija na druge potrebe i još im nepravedno zaračunava neke troškove. Kao drugu stvar navodili su kako su im franjevci bili dužni naći učitelja njemačkoga jezika, što nisu učinili, a čak su ih, navodno, spriječili da se sami pobrinu za to. U svojoj su žalbi dvojica klerika napravila i nešto netipično. Naime, jasno su istaknuli svoj status kandidata za svjetovno svećenstvo na osnovi kojega ne bi trebali stanovati s redovnicima, a također su smatrali da upravo u tome i leži glavni uzrok svih problema i međusobne netrpeljivosti. Zaključno, smatrali su da bi najbolje bilo kada bi im bilo dopušteno da napuste samostan i potraže prikladan privatni smještaj, čak i u nekome drugom gradu. Argumentacija dvojice klerika u velikoj mjeri potvrđuje ranije iznesene tvrdnje kako su zagrebački franjevci od početka pokazivali zazor ka primanju bosanskih klerika koji ipak nije bio uvjetovan negativnim predrasudama, nego nezadovoljstvom zbog zadiranja u nadležnost redovničkih provincija da same raspolažu svojim samostanima. Sama pak činjenica da se Zubčević i Vidović nisu usuđivali na vlastitu ruku napustiti smještaj kojim su ionako bili nezadovoljni, nego su morali tražiti dopuštenje, dodatno ukazuje na nesamostalnost u odlučivanju kako samih stipendista tako i njihovih franjevačkih domaćina.

Za sada nema dokumenata na osnovi kojih bi se moglo zaključiti kako je teklo rješavanje ovoga slučaja. Vidović se 9. kolovoza 1792. sam ponovo obratio na Duhovni stol tražeći dozvolu stanovanja izvan samostana, ali i premještaj u Beč. ${ }^{27}$ Ovaj premještaj je ponovo

24 Usp. NAZ NDS (OD) 1912/1789.

25 Isto, 839/1790. Int.

26 Isto, 283/1792.

27 Isto, 1022/1792. 
tražio i 20. ožujka 1793. i to obraćanjem na samoga vladara. Rješavanje ove molbe vladar je povjerio KUNV-u koji je u svibnju iste godine za to ovlastio Vrhovca, a on se dao u prikupljanje svih relevantnih informacija. ${ }^{28}$ Već u lipnju imao je sve potrebne materijale na osnovi kojih je preporučio da se Vidovića ostavi u Zagrebu, ${ }^{29}$ što je KUNV i potvrdio na sjednici točno godinu dana nakon prve Vidovićeve molbe. ${ }^{30} \mathrm{U}$ međusobnoj komunikaciji nadležnih institucija fokus se sveo na pitanje trenutačnih Vidovićevih kompetencija u njemačkome jeziku te o iznosu stipendije, a izostavljeno je pitanje boravišta. $\mathrm{Na}$ taj način ni posredno ne možemo zaključiti što se događalo sa Zubčevićem.

Njegovo se ime sljedeći put spominje u jednom dopisu kojim je KUNV tražio od Vrhovca da se pobrine za bolji uspjeh klerika u nastavi, a ovdje se konačno nalaze nekakvi podatci o mjestu i uvjetima stanovanja. ${ }^{31} \mathrm{U}$ jednom od popratnih dokumenata navedeno je kako "svi spomenuti Bosanci, u svjetovnoj odjeći, kao i Franjo Dobretić već zaređeni svećenik odjeven sukladno svomu Redu, borave izvan samostana po privatnim kućama". ${ }^{32}$ Okolnosti u kojima je do toga došlo, odnosno jesu li klerici samostan napustili skupno ili pojedinačno, na svoju ruku, inicijativu franjevaca ili neke druge nadležne instance, za sada ostaju bez odgovora. Slično je i s preciziranjem datuma gdje se može iznijeti teza kako su posljednji sekularni klerici napustili zagrebačke franjevce prilikom njihova povratka u svoj matični samostan u kolovozu $1793 .^{33}$ Kako se Zubčević nakon molbe koju je uputio zajednički s Vidovićem više ne spominje, moguće je da je prešao u privatan smještaj još u prvoj polovici 1792.

Nakon ovoga Zubčevićevo se ime pojavljuje u brojnim izvješćima, ali su podatci o njemu gotovo redovito vezani za pitanja njegova školovanja i uspjeha. Gdje je konkretno i u kakvim uvjetima stanovao, je li uopće i koliko često mijenjao adresu stanovanja, te je li stanovao sam

28 Isto, 638/1793. Int. gdje se čuva više dokumenata na osnovi kojih je rekonstruiran cijeli slučaj.

29 Isto, 698/1793.

30 Isto, 990/1793. Int.

31 Isto, 1107/1793. Int. Dopis je datiran s 1. listopada 1793.

32 Isto, "(O)mnes dicti Bosnenses in veste saeculari, prout et Franciscus Dobretich jam Sacerdos, ordini suo convenienter vestitus extra claustrum per Domos privatorum degant."

33 Usp. bilj. 22. 
ili s nekim od preostalih stipendista, pitanja su koja ostaju bez odgovora. Vasiljevićevo se ime u istom periodu spominjalo još i manje, odnosno isključivo u kontekstu školskih izvješća. Osmorica sekularnih klerika su se 27. svibnja 1796. ponovo obratila na Vrhovca tražeći pomoć. ${ }^{34}$ Razlogom njihove molbe bilo je pitanje raspolaganja njihovim stipendijama. Klerici nisu imali pravo osobno ih podizati pa su bili prinuđeni živjeti na dug, što ih je dovodilo u nelagodne situacije s njihovim stanodavcima. Stoga su molili Vrhovca da se založi da im se stipendije što prije isplate kako bi podmirili svoja dugovanja. Ovaj je problem već bio poznat KUNV-u koji je na sjednici tri dana ranije, 24. svibnja, donio odluku da se sedmorici klerika isplati uobičajenih 200 forinti godišnje stipendije, dok je Luka Marijanović, primljen na stipendiju 1792., imao pravo na samo 120 forinti. ${ }^{35}$ Vrhovac je cijeli slučaj povjerio svom protokolistu Franji Bošnjakoviću koji ga je mjesec dana kasnije izvijestio o postignutom. ${ }^{36}$ Novci su bili dostavljeni, ali je prema svemu sudeći gvardijan zagrebačkoga samostana bio osoba zadužena za njihovo podizanje. Vjerojatno smatrajući da to više nije njegova odgovornost, s obzirom da klerici više nisu stanovali u samostanu, gvardijan je odbijao podići novce i isplatiti kleričke dugove, pa su njihovi kreditori počeli salijetati samoga Bošnjakovića sa svojim zahtjevima. Nije poznato kako je završio cijeli slučaj, ali je vidljivo kako je svakodnevica klerika bila sve samo ne jednostavna i da se nikako nisu mogli u potpunosti fokusirati na učenje.

\section{Tijek školovanja Filipa Zubčevića}

Zubčević je svoje školovanje u cijelosti polazio u Zagrebu prema redovitu planu i programu koji je ondje tada vrijedio. Budući svećenici su nakon završene niže škole (tzv. "normalke") upisivali gimnaziju. U Zagrebu je u periodu od 1776. do 1842. postojala Kraljevska akademija znanosti (Academia Regia Scientiarum) čijim su sastavnim dijelovima bili Glavna gimnazija (Archigymnasium) i Akademija (Academia Scientiarum). Gimnazija je bila podijeljena na dvije niže razine: gramatiku i humaniora. Gramatika je obično trajala maksimalno 4 godine, ali sudeći prema izvješćima i analizi školskih putova bosanskih stipendista, u posljednjem desetljeću 18. st. u Zagrebu su

34 Usp. NAZ NDS (OD) 709/1796.

35 Isto, 773/1796. Int.

36 Isto, 816/1796. 
je polaznici pohađali kroz tri razreda. Nakon toga slijedila su dva razreda humaniore, koji se često nazivaju i poesis, odnosno rhetorica.

Tijekom spomenute dvije razine polaznici su pohađali različito gradivo. Njihov sadržaj se može vidjeti na jednom izvješću za Zubčevića. ${ }^{37}$ Premda su đaci učili i sadržaje kao što su geografija, opća povijest, prirodoslovlje, aritmetika i grčki jezik, naglasak je ipak bio na gradivu iz latinskoga jezika razdijeljenom u etimologiju, sintaksu i govornu praksu. Tijekom dva humaniorna razreda vještine u izražavanju na latinskom dodatno su se usavršavale upravo s ciljem da se slušače osposobi za pohađanje viših razina u kojima je latinski bio nastavnim jezikom.

Iza humaniora slijedila su dva razreda filozofije pri čemu se - kako će se vidjeti na odgovarajućem mjestu - radilo o gradivu kudikamo širega sadržaja koji je obuhvaćao područja i ostalih humanističkih, ali i prirodnih znanosti. Stoga se jedna od razina često u izvorima naziva i "fizika." Dovršetkom gimnazije, svećenički su kandidati upisivali studij teologije na tadašnjem biskupskom liceju gdje su ostajali tijekom iduće četiri godine. Klerike je, dakle, po dolasku u Zagreb očekivalo školovanje u trajanju od 11 godina.

U prethodnim dijelovima prikazano je kako su okolnosti u kojima je pohađao gimnaziju i studij bile veoma nepovoljne. O kvaliteti predznanja koje je donio iz Kreševa može se samo nagađati. Zubčević je prvi razred gramatike upisao tek šk. god. 1788./1789., dakle godinu dana po svome dolasku. Nije poznato je li u međuvremenu bio poslan na pohađanje neke normalke, kao što je to bio slučaj s nekolicinom drugih klerika. $S$ druge pak strane, neki su od klerika pristiglih kada i on sa školovanjem započeli kasnije.

Izvješća o njegovu školovanju ne mogu otkriti kako je na njega utjecala atmosfera stalnih trzavica kojom je bio obilježen njegov boravak $\mathrm{u}$ franjevačkome samostanu, kao ni kakav je utjecaj imala materijalna nesigurnost nakon prelaska u privatan smještaj. U njima se ipak nazire jedan drugi psihološki čimbenik. Bez obzira u koju od predloženih godina smjestili datum Zubčevićeva rođenja (v. gore), on je

37 Usp. HR-DAZG-102, kut. 25620 (šk. god. 1789./1790.), br. 14. Materiae in I gramaticae schola, in Archigymnasio Zagrabiensi, altero semestri anno 1789. pertractatae. U građi koja je korištena prilikom izrade ovoga rada, ovo je i jedini primjer gdje je pobliže navedeno gradivo. Sva ostala izvješća, sastavljena o polaznicima nekog od gramatičkih ili humaniornih predmeta, vrjednuju isključivo opći uspjeh i nikada ga ne razlažu prema pojedinim područjima. 
bio uvjerljivo najstariji đak u razredu. Uzme li se u obzir da se radilo o osjetljivoj dobi (1789. mogao je imati minimalno 15, a maksimalno 19 godina) te da je, povrh svega, bio jedinim klerikom s bosanskohercegovačkoga prostora u svome razredu, boravak među djecom sigurno mu nije uvijek bio ugodan. Uostalom, prvo izvješće ga po pitanju ponašanja opisuje kao taciturnus što, kada se usporedi s optužbama zagrebačkih franjevaca, sugerira da je barem te godine bio relativno usamljen. ${ }^{38}$ Ukupno gledano, nije neobično što se Zubčević nije pokazao pretjerano uspješnim učenikom. Izvješća ga smještaju među polaznike ocijenjene drugim redom, a samo su dvojica đaka bila svrstana kao lošiji od njega.

Izvješća iz šk. god. 1789./1790. iz nepoznatih razloga ispuštaju njegovo ime, ali da je tada pohađao i završio drugi razred gramatike potvrđuju ona iz sljedeće šk. god. 1790./1791. koja ga navode kao polaznika trećeg gramatičkog razreda. ${ }^{39}$ Od ukupno 37 đaka njih dvanaestorica bili su ocijenjeni drugim redom, a Zubčević je među njima zauzeo posljednje mjesto. Kako su trojica njegovih suučenika dobili treći red, nije bio najlošijim učenikom u razredu. S druge strane, vladanje mu je bilo ocijenjeno uzornim.

Iduće šk. god. 1791./1792. pohađao je prvi razred humaniora, ponovo ostvarivši uspjeh drugoga reda koji ga je još jednom smjestio među neuspješnije učenike. ${ }^{40} \mathrm{U}$ pogledu vladanja, nadležni su ga očito smatrali poslušnim (obsequens), ali izgleda da su procjenjivali da relativan neuspjeh Zubčević duguje svojoj dokonosti (otiosus). Ove dvije karakteristike dobivaju na značenju kada se uzme u obzir jedna veoma zanimljiva pojedinost iz iste školske godine. Na sjednici 7. lipnja 1791. hrvatski je Sabor zaključio da će se u hrvatske škole kao izborni predmet uvesti nastava iz mađarskoga jezika. ${ }^{41}$ Među prvim slušačima nalazio se i Zubčević. Može se samo nagađati što ga je po-

38 Isto, br. 13. Tabella morum ac studiorum iuventutis in I. schola gramaticali in Archigymnasio Zagrabiensi literis operam dantis, anno 1789. semestri altero.

39 Usp. HR-DAZG-102, kut. 25621 (šk. god. 1790./1791.), br. 14. Catalogus studiosorum $3^{\text {ae }}$ gramatices classis secundo semestri 1791. exhibitus.

40 Isto, (šk. god. 1791./1792.), br. 13. Tabella morum ac studiorum iuventutis scholasticae in I. humanit. schola in Archigymnasio Zagrabiensi, primo Semestri an. 1791/2 literis operam navantis i br. 14 Tabella morum ac studiorum iuventutis scholasticae in I. humanitatis classe in Archigymnasio Zagrabiensi, altero Semestri an. 1792 literis operam navantis.

41 Širi kontekst u kojemu je došlo do ove odluke donosi: JARosLAV ŠIDAK, Hrvatski narodni preporod - ilirski pokret, Školska knjiga, Zagreb, 1990., str. 15-21. 
taknulo na upis ovoga predmeta. Ima li se u vidu vremenski kontekst u kojemu se sve događalo, a kada su klerici napuštali stanovanje u franjevačkom samostanu, nije isključeno da se i Zubčević, jednako kao i Vidović, bavio mišlju o premještaju iz Zagreba nekamo drugamo, pri tome možda ciljajući na neku lokaciju u užoj Mađarskoj. Također, moguće je da je već i tada razmišljao o trajnom ostanku u Monarhiji pa se učenjem mađarskoga nadao stvoriti povoljne pretpostavke za to. Kako je bilo i očekivati, ni ovdje nije pokazao puno bolji uspjeh. U prvom semestru jedini je bio ocijenjen drugim redom, a isti je uspjeh pokazao i na kraju školske godine. Predavač, Juraj Šug (Georgius Sugh) u svojim opaskama naveo je kako Zubčević "osrednje čita i izgovara" te da se "čini kako mu nedostatak talenta sprečava napredak". ${ }^{42} \mathrm{~S}$ druge strane, od ionako malog broja upisanih, Zubčević je bio jedan od dvojice koji su nastavu odslušali do kraja. Humaniora je završio 1793. s već standardno ispodprosječnim uspjehom. ${ }^{43}$

Sljedeći korak predstavljalo je pohađanje filozofije čija se nastava izvodila u sklopu zagrebačke Akademije gdje se nalazila i gimnazija koju je do tada pohađao. Za razliku od gimnazijskih koja su se sastavljala samo skupno, odnosno za ukupni uspjeh, tijekom dviju godina studija filozofije predavači su sastavljali izvješća za svaki predmet posebno. Sadržaj im je pri tome uglavnom odgovarao onima s nižih razina. Jedan je dio bio posvećen biografskim podatcima za svakoga studenta te njihovu vladanju, a drugi je obuhvaćao podatke o njihovu uspjehu na semestralnim ispitima i klasificirao ih prema ukupnom redoslijedu. Kako je već ranije naglašeno, najveći dio podataka o godini i mjestu rođenja te oni o obitelji potječe iz ovih izvješća premda zbog svoje neujednačenosti i nejasne metodologije prikupljanja podataka ne pružaju mogućnost preciznoga lociranja. Kako su okvirni zaključci o biografskim podatcima prezentirani u dijelu teksta koji

42 Usp. HR-DAZG-102, kut. 25621 (šk. god. 1791./1792.), br. 9. Informatio de juventute praelectiones lingvae \& literaturae Hungaricae freqventante. Pro Semestri $1^{\circ}$ 1792. i br. 10 Informatio de juventute praelectiones lingvae \& literaturae Hungaricae freqventante. Pro Semestri $2^{\circ} 1792$. gdje je navedeno: "Legit \& enunciat mediocriter, ex Syntaxi et Versione $2^{\text {ae }}$ Classis \& defectus talentorum profectum impedire videtur." Što se ostalih polaznika tiče, uza Zubčevića nastavu je do kraja odslušao Antun Jelenčić. Od preostale trojice, dvojica su prešli kod drugoga, vjerojatno privatnoga predavača pa nisu polagali završni ispit.

43 Isto, kut. 25622 (šk. god. 1792./1793.), br. 11. Cathalogus humanistarum II. anni pro I. Semestri anni 1792/3. exhibitus i br. 12 Cathalogus humanistarum II. anni pro II. Semestri anni 1793. 
je govorio o porijeklu dvojice klerika, u nastavku veću pažnju treba obratiti na sam sadržaj gradiva koje su studenti polazili.

Prikazano je kako je Zubčević tijekom dviju nižih razina bio dobrog vladanja te da je učenjem mađarskoga jezika tijekom jedne godine pokazao i određenu marljivost, ali da je usprkos svemu njegov uspjeh bio u najmanju ruku slab, odnosno da je veoma vjerojatno uz veliku muku dobivao prolazne ocjene. Na studiju filozofije to više nije bilo dovoljno i Zubčević će umjesto dvije, ondje provesti pune četiri godine.

Prvu godinu je prvi put slušao šk. god. 1793./1794. I u prvom ${ }^{44}$ i u drugom ${ }^{45}$ semestru polagao je pragmatičku povijest Ugarske, oba puta ostvarivši drugi red uz nimalo pohvalne opaske o tome kako mu nedostaje i umnih sposobnosti i nadarenosti ("ob defectum et ingenii et adplicationis") za spomenuto gradivo. Osim toga, u prvom semestru slušao je gradivo iz logike i povijesti filozofije iz kojega je također ostvario drugi red ${ }^{46}$ te algebru i osnove geometrije gdje je dobio treći red kao najlošiji polaznik toga predmeta. ${ }^{47}$

Premda je ranije drugi red bio dovoljan za prolazak, Zubčević je sljedeće godine (1794./1795.) pohađao nastavu i polagao predmete iz svih navedenih predmeta. Iz pragmatičke povijesti u prvom je semestru po prvi put zaradio ocjenu prvoga reda, ${ }^{48}$ a u drugome je ponovo dobio drugi red. ${ }^{49}$ Iz preostala dva predmeta ponovio je identičan (ne)uspjeh: iz logike i povijesti filozofije drugi, ${ }^{50}$ a iz algebre i osnova geometrije treći red. ${ }^{51}$ Osim toga, u ovoj je godini ponovo $s$ još

44 Isto, kut. 25622 (šk. god. 1793./1794.), br. 6. Informatio de philosophis primi anni ex Historia pragmatica Hungariae pro primo semestri anni 1793/4.

45 Isto, br. 7. Informatio secundi semestris anni 1794. De progressu philosophorum primi anni in Historia pragmatica Hungariae et Caesarum.

46 Isto, br. 8. Informatio de philosophis primi anni ex Logica et Historia philosophica anno 1794.

47 Isto, br. 9. Cathalogus \& classificatio primi anni philosophorum ex Algebra et Geometria elementari $1794^{\text {ti }}$.

48 Isto, kut. 25623, br. 7. Informatio ex Historia pragmatica Regni Hungariae de philosophis primi anni pro primo semestri anni 1795.

49 Isto, br. 8. Informationes de philosophis primi anni ex Historia pragmatica Hungariae et Caesarum secundi semestris anni 1795.

50 Isto, br. 9. Informatio de philosophis primi anni ex Logica et Historia philosophica anno $1795^{\text {to }}$.

51 Isto, br. 10. Cathalogus philosophorum primi anni pro examine semestris secundi ex Algebra \& Geometria elementari adornatus. A[nno] $1795^{\circ}$. 
trojicom studenata sa svoje godine pohađao nastavu iz mađarskoga jezika ostvarivši u oba semestra prvi red. ${ }^{52}$

S obzirom na ponovljeni neuspjeh Zubčević je šk. god. 1795./1796. morao i po treći put pohađati prvu godinu studija filozofije koju je ovoga puta uspješno i dovršio. Što se tiče ispita iz pragmatičke povijesti Ugarske, u oba je semestra dobio drugi red s tim da je zbog zdravstvenih problema, koji nisu pobliže opisani, često izostajao $\mathrm{s}$ nastave. ${ }^{53}$ "Uži" filozofski predmet te je godine bio ponešto modificiran te su polaznici uz povijest filozofije slušali racionalnu filozofiju umjesto logike, no Zubčević je ostvario do tada najbolji uspjeh svrstavši se među grupu ocijenjenu prvim redom. ${ }^{54}$ Napokon, ove je godine svladao i gradivo iz algebre i geometrije dobivši, ovom prilikom prolazni, drugi red. ${ }^{55}$

Ujesen 1796. Zubčević je napokon upisao drugu godinu studija filozofije koju se zbog brojnih prirodoslovnih predmeta ponekad naziva i "fizikom." Kako se moglo i očekivati, ponovo je imao sve samo ne lagan izazov svladavanja gradiva koje mu nikako nije ležalo i o kojemu, uostalom, nije imao nikakva predznanja s obzirom da je i ranije u Kreševu, odnosno tijekom nižih razina u Zagrebu, uglavnom slušao gradivo humanističkih predmeta. U prvom semestru polazio je nastavu iz opće fizike tijekom koje je cijelo vrijeme izgledalo da će dobiti treći red i ponovo pasti, ali je na kraju iz javnoga ispita uspio dobiti drugi red. ${ }^{56} \mathrm{~S}$ nešto manje problema, a $\mathrm{s}$ istim uspjehom na javnom ispitu svladao je i predmet posvećen arhitekturi i hidroteh-

52 Isto, br. 11. Informatio de juventute praelectiones lingvae et litteraturae Ungaricae freqventante. Semestri $I^{\circ}$ anni 1794/5. i br. 12. Informatio de juventute praelectiones lingvae et litteraturae Hungaricae freqventante. Semestri secundo 1795. Predavač je ponovo bio Juraj Šug.

53 Isto, kut. 25624, br. 5. Informatio de philosophis primi anni ex Historia pragmatica Hungariae \&c. Primi semestris anni 1796 i br. 6 Informatio ex Historia pragmatica Hungariae secundi semestris et Romanorum Imperatorum de philosophis primi cursus anni 1796.

54 Isto, br. 7. Informatio de philosophis primi anni ex Philosophia rationali et $\mathrm{Hi}$ storia philosophiae pro primo semestri anni $1796^{t i}$.

55 Isto, br. 8. Cathalogus philosophorum $1^{m i}$ anni, anni $1796^{t i}$ cum eorumdem classi[fica]tione pro examine semestrali ex Algebra et Geometria elementari.

56 Isto, kut. 25625, br. 1. Informatio de philosophis secundi anni ex Physica generali sub finem primi semestris anno MDCCXCVII. 
nici. ${ }^{57} \mathrm{U}$ drugom semestru u jednom izvješću sačuvani su podatci za ispite iz metafizike i filozofije morala gdje je Zubčević u oba slučaja zaslužio tek treći red. ${ }^{58}$ Zajedno su vođeni i podatci za fiziku i agronomiju na čijim je ispitima dobio drugi red. ${ }^{59}$ Budući da je čak iz dva predmeta dobio ocjenu trećeg reda, očekivalo bi se da Zubčević ponavlja i drugu godinu studija, ali se to ipak nije dogodilo. Kontekst ovakve odluke bit će jasniji kada se promotri njegov boravak na studiju teologije, kao i skupna sudbina sekularnih klerika. Kako će se cijela situacija odraziti i na sudbinu Josipa Vasiljevića, radi lakše preglednosti i izbjegavanja ponavljanja najprije će biti prikazan njegov tijek školovanja na prve tri razine.

\section{Tijek školovanja Josipa Vasiljevića}

Ako se kao realnu činjenicu prihvati da je Zubčević tijekom pohađanja gimnazije i studija filozofije ostvario u najmanju ruku skroman uspjeh velikim dijelom i zbog neadekvatnoga predznanja, kod njegova je zemljaka situacija bila još i nepovoljnija. Iako su u Zagreb stigli zajedno, Vasiljević je u gimnaziju primljen tek šk. god. 1790./1791. Vrijeme između nije proveo besposlen. Prvo izvješće u kojemu je ubilježeno njegovo ime navodi da je s još trojicom sekularnih klerika prethodnu godinu pohađao II. razred tzv. "normalke" s čijim je završavanjem također imao problema ostvarivši uspjeh drugoga reda. ${ }^{60}$ Isto je ponovio i na kraju prvoga semestra, kao i na kraju razreda. ${ }^{61}$ Sljedeće godine je znatno popravio svoj uspjeh tako da se na kraju oba semestra svrstao među učenike prvoga reda s time da je napredovao i u ukupnu poretku pa je prvi semestar završio kao 16. od 22 učenika

57 Isto, br. 2. Cathalogus et classificatio philosophorum secundi anni ex Architectura et Hydrotechnia pro examine semestris primi Anni 1796/7 adornata.

58 Isto, br. 3. Informatio de philosophis secundi anni sub finem anni 1797. ex Metaphysica.

59 Isto, br. 4. Informatio de philosophis secundi anni ex Physica \& Re rustica sub finem secundi semestris anno M.D.CC.XCVII. Iz samih izvješća nije razvidna razlika između predmeta opće fizike i fizike.

60 Isto, kut. 25621 (šk. god. 1790./1791.), br. 17. Calculus studiosorum anno I. grammaticae in Archigymnasio Regio Zagrabiensi operam navantium anno 1790/91.

61 Isto, br. 18. Calculus studiosorum anno I. grammaticae in Archigymnasio Regio Zagrabiensi operam navantium pro II ${ }^{\text {do }}$ Semestri 1790/91. 
s prvim redom, a drugi kao 9. od njih $26 .{ }^{62}$ Istim je žarom nastavio i sljedeće godine dovršivši gramatiku kao polaznik prvoga reda ${ }^{63}$ Kako je već naglašeno, nakon što su riješene najveće razmirice između zagrebačkih franjevaca i bosanskih klerika, teško je pratiti njihovu pojedinačnu sudbinu mimo izvješća o školskom uspjehu. Vasiljević je nedvojbeno promijenio svoje ponašanje nabolje jer ga rubrike vezane uz vladanje i pobožnost ističu u vrlo povoljnom svjetlu.

Dvije godine humaniore također je završio bez većih problema, prvu šk. god. 1793./1794. ${ }^{64}$ a drugu 1794./1795. ${ }^{65}$ Izvješća ga redovito smještaju među učenike prvoga reda, ali ovaj uspjeh ne treba predimenzionirati. Tako ocijenjeni polaznici redovito su činili većinu u ukupnu broju učenika nekog razreda, a Vasiljević se nikada nije uspio približiti onom samom vrhu i dobiti eminens kao najvišu ocjenu. Osim toga, premda ne postoje ni naznake da je izazivao probleme slične ranijima, vladanje mu se ipak ponešto pogoršalo i te ga rubrike smještaju u drugi red. Premda je u tom periodu nedvojbeno bio među uspješnijim klericima iz osmanske Bosne uopće, Vasiljević nije pohađao izbornu nastavu iz mađarskoga jezika. ${ }^{66}$

Kada je Vasiljević šk. god. 1795./1796. upisao studij filozofije, dospio je u razred zajedno sa Zubčevićem koji je te godine po treći put pohađao nastavu prve godine. Kao i njegov zemljak, i Vasiljević je

62 Isto, kut. 25621 (šk. god. 1791./1792.), br. 17. Calculus studiosorum anno II. grammaticae in Archigymnasio Regio Zagrabiensi operam navantium anno 1791/92. i br. 18. Calculus studiosorum anno II dae grammaticae classi in Archigymnasio Regio Zagrabiensi operam navantium anno 1791/92. pro II. semestri.

63 Isto, kut. 25622 (šk. god. 1792./1793.), br. 13. Relatio de profectu studiosorum III. grammaticae classi in Reg. Archigymnasio Zagrabiensi operam navantium pro primo semestri 1793. i br. 14. Calculus studiosorum in Archigymnasio Zagrabiensi R. III. grammaticae classi operam navantium anno 1792./93. pro $2^{\text {do }}$ semestri.

64 Isto, kut. 25622 (šk. god. 1793./1794.), br. 14. Tabella morum ac studiorum juventutis scholasticae in $I^{a}$ humanitatis classe in Archigymnasio Zagrab. $1^{\circ}$ semestri an. 1793/4. literis operam navantis i br. 15. Tabella morum ac studiorum iuventutis scholasticae in I. humanitatis classe in Archigymnasio Zagrabiensi primo semestri an. 1793/4. literis operam navantis.

65 Isto, kut. 25623, br. 13. Cathalogus humanistarum II. anni pro $1^{\circ}$ semestri, anni 1795. i br. 14. Informationes auditorum II. Humanitatis pro Semestri II., anno 1795.

66 Osim Zubčevića, među bosanskim klericima mađarski je slušao još samo Pavao Nikolić, rođen u Kreševu. 
na toj razini znatno pogoršao uspjeh. Iz pragmatične povijesti u oba je semestra ostvario drugi red, isti je uspjeh ostvario i iz algebre i osnova geometrije, a najlošiji je bio iz racionalne filozofije i povijesti filozofije gdje je svrstan među polaznike trećega reda. Premda bi se očekivalo da će zbog ovoga posljednjeg morati ponavljati godinu, Vasiljeviću je ipak dopušten upis druge godine na kojoj se, očekivano, nije proslavio. Samo je iz fizike i agronomije dobio drugi red, dok je iz svih ostalih predmeta (opća fizika, arhitektura i hidrotehnika, metafizika i filozofija morala) ostvario treći red. ${ }^{67}$ Zbog toga je šk. god. 1797./1798. ponavljao drugu godinu, ali ponovo veoma neuspješno. Od četiri spomenuta predmeta iz njih tri je ponovo dobio tek treći red, a iz jednoga uopće nije izašao na završni ispit. ${ }^{68}$ Očekivalo bi se da će student s takvim ocjenama morati još jednom ponavljati godinu, ali Vasiljević je to ponovo izbjegao. Kontekst takve odluke bit će jasniji ukoliko se promotri sa širega gledišta promijenjenih okolnosti na vanjskopolitičkom planu.

\section{Prenamjena stipendije i sudbina preostalih sekularnih klerika}

Školovanjem sekularnih klerika habsburška je politika željela pripremiti teren za uspostavljanje redovite dijecezanske strukture u Bosni oslonjene na domaći kadar. Glavnim preduvjetom za provođenje takvih planova bio je ipak vojni uspjeh u ratu protiv Osmanlija koji je, suprotno svim očekivanjima, izostao nakon polovično uspješnoga Dubičkog rata (1788. - 1791.) zaključenog Mirom u Svištovu. Iako time nije nestao habsburški interes za proširenjem na Bosnu, novi vanjskopolitički zapleti uzrokovani izbijanjem Francuske revolucije na dulji će period onemogućiti ikakvu agresivnu politiku prema Osmanlijskom Carstvu. U takvome kontekstu zaklada Josipa II. iz-

$67 \mathrm{Za}$ navedene dvije godine usporedi podatke $\mathrm{u}$ bilješkama ispod dijela teksta koji se odnosi na Zubčevića.

68 Usp. HR-DAZG-102, kut. 25626, br. 1. Informatio de philosophis secundi anni ex physica sub finem primi semestris anno MDCCXCVIII, br. 2. Cathalogus et classificatio philosophorum II anni ex Architectura et Hydrotechnia pro examine semestris $1^{i}$ anni 1797/8. adonrata, br. 3. Informatio de philosophis $I^{d i}$ anni ex Metaphysica \& Philosophia morali sub finem anni scholastici $1798^{v i} \mathrm{i}$ br. 4. Informatio de juventute praelectiones physicas \& Rei rusticae semestri II ${ }^{\circ}$ 1798 excipiente in Regia Academia Zagrabiensi. Vasiljević nije polagao ispit iz metafizike i filozofije morala. Kao razlog navedena je nekakva bolest, ali bez konkretnijih podataka. 
gubila je svoju prvotnu namjenu, ali Dvor i Kraljevsko ugarsko namjesničko vijeće ipak nisu odustali od nje, a za nju je živi interes počela pokazivati i sama Bosna Srebrena.

Ostankom Bosne pod vlašću Osmanlija franjevci su zadržali svoj specifičan položaj nositelja katoličkih struktura što je za sobom povlačilo i materijalne poteškoće koje su se ponovo u velikoj mjeri odražavale na odgoj i školovanje mladih kadrova. Odjek ideja Francuske revolucije u Italiji, a osobito dolazak francuske vojske onamo u posljednjem desetljeću 18. st. u sve je većoj mjeri onemogućavao slanje bosanskih klerika u tamošnje franjevačke provincije. Habsburška Monarhija nametala se kao jedino rješenje i upravo u ovom periodu zaklada Josipa II. doživjet će svoju transformaciju - od sredstva koje je trebalo omogućiti istiskivanje franjevaca sa župa, posta(ja)la je osnovicom njihova obrazovanja, ali i lojalnosti habsburškom vladaru kao liniji politike koju je Bosna Srebrena nedvosmisleno slijedila sve do obrata nastalog pojavom ilirskoga pokreta i širenjem njegovih ideja.

Sekularni klerici su u takvu kontekstu sve više bili prepuštani samima sebi. Ilustrativan zaokret vidlijiv je u već opisanom slijedu događaja u sklopu kojih će ovi mladići biti prinuđeni potražiti privatan smještaj. Tom prilikom iz zagrebačkoga samostana udaljeno je i nekoliko franjevačkih klerika, ali su se vlasti pobrinule da im nađu smještaj u nekom od ostalih franjevačkih samostana. Tako je jedna veća skupina boravila u Velikoj odakle su krajem 1796. i početkom 1797. bili premješteni u ponovo otvoreni samostan u Požegi. Kako je do toga vremena nekoliko sekularnih klerika već bilo napustilo školovanje, njihove stipendije su dodjeljivane mladim franjevcima čiji je broj neprestano rastao. ${ }^{69}$ Do trenutka kada je Zubčević ujesen 1797. upisao studij teologije od sekularnih klerika su na školovanju preostala samo šestorica: Jure Kordić koji je dotada već dovršio kompletan studij i tražio način kako se vratiti kući, ${ }^{70}$ Anto Nikolić koji je tada također upisivao teologiju, Ivan Alović tada polaznik prve godine studija filozofije, Luka Marijanović u prvom razredu humaniora, te naslovni dvojac - Vasiljević i Zubčević.

69 Detaljniji prikaz razvoja ideje ove zaklade vidi u: Rudolf BARIšıć, "Intervencije Maksimilijana Vrhovca u proces stipendiranja klerika Bosne Srebrene", u: Croatica christiana periodica - časopis Instituta za crkvenu povijest Katoličkog bogoslovnog fakulteta Sveučilišta u Zagrebu, vol. XLI., br. 80, Zagreb, 2017., str. 49-73.

70 Usp. R. BARIšić, "Školovanje Jure (fra Petra) Kordića", str. 180. 
Svi su se oni u tom trenutku suočavali i s pitanjem svoje daljnje sudbine što je utjecalo i na odnos prema njima. Upravo u želji da se njihovim dovršavanjem studija što prije oslobode mjesta za primanje novih franjevačkih stipendista, treba gledati uzrok zbog kojega je Zubčeviću, a osobito Vasiljeviću tijekom studija filozofije bilo progledano kroz prste usprkos nemogućnosti da polože ispite iz nekih predmeta.

U takvim okolnostima neizvjesnosti vlastite sudbine, provodili su i studij teologije koji je Zubčević, kako je rečeno, upisao 1797., a Vasiljević godinu dana kasnije, obojica na biskupskom liceju u Zagrebu. I na ovoj su razini podnošena redovita izvješća o napretku kandidata, a identičan je bio i sustav ocjenjivanja.

U prvom semestru Zubčević je polagao grčki jezik i hermeneutiku, ${ }^{71}$ $\mathrm{u}$ drugom hermeneutiku Novoga Zavjeta, ${ }^{72}$ dok je kanonsko pravo slušao u oba. ${ }^{73} \mathrm{Na}$ svim ispitima ostvario je drugi red. Nastava je iz nekih predmeta bila organizirana na način da su studenti dviju različitih godina zajednički slušali određene predmete. Takav je slučaj prisutan i tijekom šk. god. 1798./1799. kada je Zubčević pohađao drugu, a Vasiljević prvu godinu studija. Studenti svih četiriju godina zajednički su pohađali nastavu iz moralne teologije i to oba semestra. U prvome su obojica ostvarili drugi red ${ }^{74}$ dok na kraju drugoga Zubčević zbog bolesti nije polagao javni ispit. ${ }^{75}$ Klerici su zajedno odslušali i dogmatsku teologiju. U prvom semestru Zubčević je dobio

71 NAZ Arhiv Nadbiskupskoga bogoslovnog sjemeništa (dalje: NBS), Školska izvješća (dalje: Šk. izv.) 8, Classificatio Auditorum Theologiae secundi et primi Anni ex Materiis primi Semestris anni Scholastici 1797/8. tum ex Examinibus privatis, cum etiam ex publico primo Semestrali Examine obtento.

72 Isto, Classificatio Auditorum Sacrae Hermeneuticae Novi Testamenti Secundo Semestri Anni Scholastici 1797/8. ex Examinibus tam privatis, quam Secundo Semestrali publico obtento.

73 Isto, Classificatio Auditorum Juris Canonici in Seminario Dioecesano Zagrabiensi pro primo Semestri Anni Scholastici 1797/8. i Classificatio Auditorum Juris Canonici in Lycaeo Episcopali Zagrabiensi pro 2. Semestri Anni Scholastici $1797 / 8$.

74 Isto, Šk. izv. 9, Classificatio Auditorum Theologiae Moralis ex publico, et privatis primi Semestris anni 1798/9. Examinibus.

75 Isto, Classificatio Auditorum Theologiae Moralis ex publico, et privatis examinibus pro Altero Semestri 1799. anni. U opaskama ponovo nije navedeno o kakvoj se bolesti radilo, nego samo da bi na osnovi privatno održanog ispita Zubčević - jednako kao i Vasiljević iz javnog - imao drugi red. 
drugi red, a Vasiljević treći. ${ }^{76} \mathrm{U}$ drugom semestru spominje se samo Zubčević koji ni iz ovoga predmeta nije mogao pristupiti javnom polaganju, dok je Vasiljevića vjerojatno pad u prvom semestru diskvalificirao od daljnjega pohađanja. ${ }^{77}$ Kasnija izvješća ih ne spominju, ali na osnovi drugih izvora znamo da su i tijekom 1799./1800. barem dio godine nastavili sa studijem.

Kako je već rečeno, njihov se pravni položaj neprestano pogoršavao. Bližeći se svomu kraju, njihovo se školovanje činilo sve manje svrsishodnim i postajali su smetnjom otvaranju mjesta za prijem većega broja franjevačkih klerika. Ovaj se problem osobito intenzivirao uspješnim prodorom francuske vojske u Italiju čime su tamošnji samostani na neko vrijeme morali zatvoriti vrata prijemu bosanskih klerika. Do spomenutoga trenutka, odnosno posljednje godine boravka u Zagrebu, Kordić i Alović su već odlučili svoju sudbinu vezati za Bosnu Srebrenu i vrativši se u Kreševo, ondje su - više od desetljeća nego li su to izvorno trebali napraviti - stupili u novicijat. ${ }^{78}$ Alović je pri tome na svoju ruku napustio studij filozofije ne dovršivši ga, ali mu zbog toga u Bosni nitko nije pravio pretjerane probleme. Sa Zubčevićem i Vasiljevićem posljednjih je godina studij filozofije i teologije polazio i Anto Nikolić rođen u Kreševu. On nije pokazivao interes za povratkom u Bosnu i u srpnju 1797. podnio je molbe na KUNV i Maksimilijana Vrhovca kojima je tražio dopuštenje za promjenu jurisdikcije, odnosno da po dovršetku studija teologije bude zaređen za svećenika zagrebačke biskupije. ${ }^{79}$ Njezino se rješavanje ponešto oteglo, a također je valjalo dobiti i privolu kako Vrhovca, tako i Okića kao biskupa Nikolićeve matične biskupije koja je sastavljena 8. siječnja 1799., a u Zagreb je stigla u svibnju iste godine. ${ }^{80}$

Tijekom ovoga razdoblja u spisima Duhovnoga stola nešto se češće spominje Vasiljević, premda u ne baš pohvalnom svjetlu. Najprije je 27. studenog 1798. KUNV pisao Vrhovcu opominjući kako su prema svim izvješćima Vasiljević i Alović, koji je tada još uvijek boravio u Zagrebu, na glasu kao neuspješni studenti problematičnoga vlada-

76 Isto, Classificatio Auditorum Theologiae Dogmaticae tam ex privatis, quam publico Semestrali Examine primo Semestri anni Scholastici 1798/9.

77 Isto, Informatio Alumnorum, tam Theologorum, quam Philosophorum Seminarii Episcopalis Zagrabiensis, Secundi Semestris Anni Scholastici 1799.

78 Usp. R. BARIšIĆ, nav. dj., str. 181.

79 Usp. NAZ NDS (OD) 824/1797.

80 Isto, 822/1799. 
nja. ${ }^{81}$ Vijeće se interesiralo za Vrhovčevo mišljenje bi li spomenuti dvojac pokazao napredak kada bi ih se smjestilo u neki od franjevačkih samostana ili u biskupijsko sjemenište. Zagrebački je biskup odgovorio da smještaj kod franjevaca nije moguć budući da Vasiljević i Alović nisu polagali redovničke zavjete. U sjemeništu pak više nije bilo mjesta. Stoga je Vrhovac smatrao da ih se ukoliko ne dođe do poboljšanja u njihovu vladanju i uspjehu jednostavno izbaci sa školovanja i vrati u Bosnu. KUNV se s time i složio. ${ }^{82}$

Završni udarac obrazovanju sekularnih klerika uslijedio je nakon molbe Bosne Srebrene da se osmoricu njezinih klerika iz Italije premjesti u Habsburšku Monarhiju o čemu je KUNV donio zaključke na svojoj sjednici 10. prosinca $1799 .{ }^{83}$ Uprava Provincije se 26 . listopada 1799. s navedenom molbom obratila na cara i kralja Franju II. koji je njezino rješavanje povjerio KUNV-u. Na spomenutoj sjednici Vijeće je odlučilo udovoljiti zahtjevu Bosne Srebrene. Da bi se namakla sredstva potrebna za njihovo uzdržavanje planirano je udaljavanje preostalih sekularnih klerika. U zaključcima se nalazi 6 imena: uz Vasiljevića i Zubčevića, tu su još i Marijanović, Nikolić, Alović ${ }^{84}$ i franjevac Franjo Dobretić koji se tada nalazio u Pečuhu. KUNV je želio dobiti podatke o njihovu trenutačnom napretku na školovanju i vladanju, no bilo je očito da ništa više nije moglo utjecati na promjenu namjere da im se oduzmu stipendije. Duhovni stol odaslao je obavijesti na više adresa. Bosna Srebrena obaviještena je o tome da se njezin zahtjev nalazi u postupku rješavanja i opomenuta da ne žuri sa slanjem osmorice klerika prije dobivanja formalnoga odobrenja, a od Franje Lehnana, prodirektora zagrebačke Akademije, zatraženi su podatci o školskom uspjehu preostalih klerika. Napokon, 9. svibnja 1800. Vrhovac je osobno pisao KUNV-u i podnio kratak izvještaj o trojici sekularnih klerika: Marijanoviću, Zubčeviću i Vasiljeviću. O prvome je naveo samo da se nalazi na studiju filozofije i da trenutačno nema drugih podataka. Zubčević je kao student teologije dobio pohvale kao discipliniran i dobrog vladanja, a isto tako je navedeno

81 Isto, 1424/1798. Int.

82 Isto, 421/1799. Int. Alović je do tada već na svoju ruku napustio Zagreb.

83 Zaključci te sjednice, kao i čitav niz drugih spisa vezanih uz rješavanje toga premještaja čuvaju se pod NAZ NDS (OD) 87/1800.

84 Vijeće je bilo upoznato s time da je on već napustio školovanje, ali je navodilo njegovo ime kao jednu od stipendija koje stoje na raspolaganju za dodjelu franjevačkim klericima. 
kako je u posljednje vrijeme pokazao i određeni napredak u učenju. Što se pak tiče Vasiljevića, on je tijekom zime bio podnio molbu đakovačkom biskupu za primanje u redove tamošnje biskupije i nakon njezina pozitivnog rješavanja prešao je onamo. Za sada nema podataka o tome kada je Vasiljević i kojim kanalima podnio ovu molbu, kao što nije moguće utvrditi zbog čega se odlučio za đakovačku, umjesto kao i Nikolić za zagrebačku biskupiju. KUNV je 1. srpnja 1800. donio odluku o oduzimanju stipendija Dobretiću, Marijanoviću, Vasiljeviću i Zubčeviću uz neodređenu opasku o njihovu povratku u Bosnu. ${ }^{85}$

Zubčević se 24. kolovoza obratio na Vrhovca pismom iz čijeg je sadržaja jasno da je bio primio obavijest o dokidanju stipendije. ${ }^{86} \mathrm{Uz}$ uobičajene izraze zahvalnosti na pruženim dobročinstvima, Zubčević je u drugomu dijelu pisma prešao na pravi predmet svoga obraćanja. Budući da mu je obustavljena stipendija, klerik je molio Vrhovca da se kod KUNV-a založi da mu se odobri novčana pomoć kojom bi pokrio troškove stanovanja i vlastitoga uzdržavanja nakon 1. studenoga te također financirao put kući. Vrhovac je to i učinio 12. rujna odgovarajući na jedan drugi dopis KUNV-a. ${ }^{87}$ Vijeće je 7. listopada odobrilo 10 forinti na ime putnih troškova i ovlastilo Vrhovca da se spomenuta svota što prije isplati. ${ }^{88}$ Zubčevićevo se ime spominje još samo jedanput u izvorima, ali u prilično uzgrednom kontekstu. Mato Kristićević, franjevac koji je s bosanske strane pratio cijeli postupak oko oduzimanja stipendija sekularnim i njihova dodjeljivanja franjevačkim klericima 25. studenog 1800. pisao je Vrhovcu tražeći neka razjašnjenja oko spomenutih odluka ${ }^{89} \mathrm{U}$ Bosnu su stigla dva dopisa čije su obavijesti pružale mogućnost da se tumače kao dozvola za slanje ili tri ili četiri klerika pa je od Vrhovca zatraženo razjašnjenje. Tom prilikom posljednji se put govori o Marijanoviću, Vasiljeviću i Zubčeviću, ali na način da se samo spominju njihova imena. Već je navedeno da su samo za Zubčevića sačuvani podatci koji sugeriraju da je krenuo na put prema svome domu. Uzme li se u obzir da je spomenuta odluka Vijeća u Zagreb stigla početkom studenoga, opravdano je zaključiti kako je klerik vjerojatno još istog mjeseca

85 Isto, 871/1800. Int.

86 Isto, 948/1800.

87 Isto, 1027/1800. Int.

88 Isto, 1291/1800. Int.

89 Isto, 124/1801. 
napustio Zagreb. Povuče li se, naime, usporedba s Kordićem čiji se odlazak dvije godine ranije bio otegnuo, vidljivo je kako su njegovim produljenim boravkom nastali troškovi koje je trebalo pokriti pa je o tome sačuvana korespondencija u Nadbiskupijskom arhivu. ${ }^{90}$ Izostanak ikakvih Zubčevićevih kasnijih obraćanja pruža dakle snažne indicije kako je nakon 13 godina boravka u Zagrebu krajem 1800. ili početkom 1801. stigao kući.

\section{Neke pretpostavke}

Premda mnoga pitanja, kao primjerice ono o preciznoj dobi ili mjestu rođenja, i dalje ostaju otvorena, te usprkos tome što nam svakodnevica dvojice hercegovačkih kandidata za svećenstvo tijekom njihova boravka u Zagrebu i dalje najvećim dijelom ostaje u sferi općenitih zaključaka, ipak je njihovo školovanje za sada još uvijek najbolje dokumentirani isječak iz njihovih biografija. Njihova imena naizgled nestaju iz povijesti nakon što su 1800. u završnoj fazi studija teologije bili prinuđeni napustiti stipendiju i školovanje, ali postoje neke indicije koje otvaraju put daljnjem istraživanju njihove sudbine. Da bi se ovom prilikom postavio određeni okvir, nužno se u obzir moraju uzeti i imena Luke Marijanovića i Ante Nikolića te promotriti i njihova moguća daljnja sudbina.

Vidjeli smo da su Vasiljević i Nikolić svoju sreću odlučili potražiti izvan bosansko-hercegovačkoga prostora prelaskom u svećenstvo đakovačke, odnosno zagrebačke biskupije. Pitanje ostvarenja ovih planova ipak treba uzeti s određenim oprezom. Naime, usprkos tome što je dobio sve potrebne dozvole, Nikolićevo se ime ne nalazi niti u knjigama svećenika ređenih u zagrebačkoj biskupiji, ${ }^{91}$ niti ga nalazimo među župničkim prisegama. ${ }^{92} \mathrm{Na}$ taj način postoji više mogućih verzija njegove sudbine - od toga da je napustio studij teologije i svećenički poziv općenito, zatim da je možda i umro prije nego li je mogao biti zaređen ili biti postavljen nekamo za župnika do toga da se u konačnici možda i vratio u Bosnu.

90 Usp. R. BARIŠIĆ, nav. dj., str. 180-181.

91 NAZ III. Protocolla varia, 9b Liber ordinatorum 1752.-1830.

92 Usp. StJePan Razum, Vjeroispovijedi i prisege Zagrebačke nadbiskupije: Professiones fidei et iuramenta parochorum ecclesiae Zagrabiensis, 1648.-1997., Društvo za povjesnicu Zagrebačke nadbiskupije "Tkalčić", Zagreb, 2010. 
Dostupni šematizmi Bosansko-srijemske biskupije dopuštaju da se makar unekoliko rekonstruira daljnja Vasiljevićeva sudbina. Tako je osim preciznog datiranja njegova rođenja, poznat i datum svećeničkoga ređenja koje se nesumnjivo odigralo u Đakovu 17. kolovoza $1800 .{ }^{93} \mathrm{Na}$ mrežnim stranicama Austrijske nacionalne knjižnice (Österreichische Nationalbibliothek) dostupno je više godišta šematizama (kalendara i kataloga) Bosansko-srijemske biskupije na osnovi kojih se unekoliko može rekonstruirati Vasiljevićev svećenički put. ${ }^{94}$ Najstariji sačuvani datira iz 1808. i prema njemu Vasiljević je u to doba vršio župničku službu u Berku gdje je vjerojatno bio i prvim župnikom, budući da je župa osnovana godinu dana ranije, 1807. godine. ${ }^{95}$ Slični podatci nalaze se i u šematizmu za 1809 . godinu, dok izdanje iz 1810. nije sačuvano. Najkasnije 1811. Vasiljević je dobio premještaj nešto južnije, u župu Račinovci u blizini Županje. ${ }^{96}$ Župa je u to doba imala 2315 vjernika od kojih je 640 stanovalo u samim Račinovcima, dok su ostali živjeli u njezinim filijalama: Gunji (678), Strošincima (532), Đurićima (266) i Jameni (199) gdje su činili manjinu u odnosu na pravoslavno stanovništvo čiji je broj na cjelokupnom području župe iznosio 932, od čega u samoj Jameni 889. Ni u Rači-

93 Usp. Schematismus 1835., str. 93.

94 Upute na ovu stranicu, kao i literaturu spomenutu kasnije u bilješkama, koja obrađuje crkvenu povijest prostora organiziranoga u okviru današnje Đakovačko-osječke nadbiskupije dala mi je Ankica Landeka, voditeljica Središnje nadbiskupijske i fakultetske knjižnice u Đakovu na čemu joj srdačno zahvaljujem.

95 Usp. Calendarium diaecesanum venerabilis cleri diaecesium Bosnensis seu Diakovariensis et Sirmiensis canonice unitarum pro anno a Christo nato MDCCCVIII bissextili dierum CCCXLVI cum duplici indice locorum et personarum, Budae, Typis Typographiae Regiae Universitatis Hungaricae (dalje: Schematismus 1808.), dostupno na: http://digital.onb.ac.at/OnbViewer/viewer. faces?doc=ABO_\%2BZ207718209 (zadnji pristup 14. veljače 2018.), str. 32. Uz Berak u kojemu je tada stanovalo 618 katolika, župa je obuhvaćala i naselja Čakovci (351), Negoslavce (27) i Orolik (99). Ukupan broj katolika iznosio je, dakle, 1095 i u odnosu na pravoslavce, kojih je bilo 1494, činili su manjinu. Potonji su bili osobito brojni u Negoslavcima (785) i Oroliku (394) gdje su činili većinu stanovništva, dosta ih je bilo i u Čakovcima (270), dok ih je u samom Berku bilo 45 .

96 Usp. Calendarium diaecesanum venerabilis cleri diaecesium Bosnensis seu Diakovariensis et Sirmiensis canonice unitarum pro anno a Christo nato MDCCCXI communi dierum CCCXLV cum duplici indice locorum et personarum, Budae, Typis Typographiae Regiae Universitatis Hungaricae (dalje: Schematismus 1811.), dostupno na: http://digital.onb.ac.at/OnbViewer/viewer. faces?doc=ABO_\%2BZ207718404 (zadnji pristup 14. veljače 2018.), str. 47. 
novcima se nije zadržao dugo i već je 1813. godine premješten u Otok u zapadnom Srijemu gdje će pastoralno djelovati do smrti. ${ }^{97} \check{Z}$ upa nije imala niti jednu filijalu, a tada je imala 2173 vjernika, uz koje su u mjestu stanovala i 64 pravoslavca. Pred sam kraj života doživio je i određeno priznanje za svoj dugotrajni rad jer je 1837. bio proglašen za počasnoga katedralnog kanonika bosansko-srijemske biskupije. ${ }^{98}$ Umro je u Otoku 23. listopada 1837.99

Sve ovo ne bi bilo potrebno da ne postoji snažan trag da se jedan od sekularnih klerika vratio u Apostolski vikarijat u Bosni i ondje djelovao kao svećenik. Apostolski vikar Augustin Miletić u izvješću o svojoj pastoralnoj vizitaciji, koju je obavio 1813., naveo je kako se među njemu podređenom kleru nalazi i jedan "sacerdos saecu-

97 Usp. Calendarium diaecesanum venerabilis cleri diaecesium Bosnensis seu Diakovariensis et Sirmiensis canonice unitarum pro anno a Christo nato MDCCCXIII communi dierum CCCXLV cum duplici indice locorum et personarum, Budae, Typis Typographiae Regiae Universitatis Hungaricae (dalje: Schematismus 1813.), dostupno na: http://digital.onb.ac.at/OnbViewer/viewer. faces?doc=ABO_\%2BZ207718507 (zadnji pristup 14. veljače 2018.), str. 30. Prema podatcima prezentiranima u: AnTo PAVlović, Đakovačko-osječka nadbiskupija, nekada i danas, Nadbiskupski ordinarijat, Đakovo, 2013., str. 294. Vasiljević se kao župnik u Otoku navodi već od 1812. godine. S druge strane, šematizam za istu godinu ga navodi kao još uvijek župnika u Račinovcima. Usp. Calendarium diaecesanum venerabilis cleri diaecesium Bosnensis seu Diakovariensis et Sirmiensis canonice unitarum pro anno a Christo nato MDCCCXII bissextili communi dierum CCCXLVI cum duplici indice locorum et personarum, Posonii, Typis typographi Caroli Caspari Snichek (dalje: Schematismus 1812.), str. 46.

98 Usp. Schematismus venerabilis cleri dioecesium Bosnensis seu Diakovariensis et Syrmiensiscanonice unitarum pro anno a Christo nato MDCCCXXXVII, dierum CCCLXV, Pestini, Typis Josephi Reimel, C. R. Priv. Strigoniensis Typographiae, ac unius e Pestanis proprietarii (dalje: Schematismus, 1837.), dostupno na: http://digital.onb.ac.at/OnbViewer/viewer.faces?doc=ABO_\%2BZ207719603 (zadnji pristup 14. veljače 2018.), str. 8 gdje stoji: "Canonici Honorarii: (...) Reverendissimus D. JOSEPHUS VASSILJEVICH, Cathedralis Ecclesiae Bosnensis seu Diakovariensis Canonicus Honorarius et Parochus Ottokiensis, I. Cottus Syrmiensis Tab. Jud. Assessor."

99 Usp. Antun Jarm, Dijecezanski svećenici koji su djelovali na sadašnjem području Biskupije Đakovačke i Srijemske: od 1701. do 2003. godine, Biskupski ordinarijat, Đakovo, 2003., str. 73. Autor atribuira Vasiljevića kao "bivšeg franjevca" ne navodeći pri tom izvore. Vjerojatno ga je na takav zaključak navelo Vasiljevićevo regionalno porijeklo što samo pokazuje koliko je rašireno poistovjećivanja povijesti Katoličke crkve na bosansko-hercegovačkom prostoru $\mathrm{s}$ franjevaštvom. 
laris". ${ }^{100}$ Tko bi mogao biti spomenuti? Kao prvo rješenje nametao bi se netko od popova glagoljaša koji su do 30 -ih godina 19. st. bili aktivni osobito u livanjskom, duvanjskom i krajevima uz granicu s Dalmacijom, ali takav je odgovor zanijekan iz samoga izvješća koje jasno naznačuje i 10 glagoljaša koji su označeni kao "presbyteri" kao jasan znak razlikovanja u odnosu na svećenike ("sacerdotes") kako su označavani franjevci. Iako je vremenom između dviju grupa nastala suradnja, franjevci su, a osobito apostolski vikari, uvijek s oprezom gledali na glagoljaše pri čemu su, između ostaloga, kao vlastitu prednost isticali pripadnost latinskom obredu. ${ }^{101}$ Prema tome, i u spomenutom se slučaju radilo o svećeniku čiji su se odgoj i obrazovanje odvijali u skladu s odredbama važećim na Zapadu.

Kao drugo, jednako tako prilično neuvjerljivo rješenje mogla bi se iznijeti pretpostavka da se radilo o došljaku sa Zapada koji je nekim poslom boravio u Bosni. Na području trebinjske biskupije, jedinom dijelu otomanske Bosne koji nije pripadao apostolskom vikarijatu, zabilježen je boravak nekolicine isusovaca sredinom 19. st. Slučaj u kojemu su katolički svećenici sa Zapada boravili u Bosni i izvan nekakve vizitacije ili diplomatske misije bio je, uostalom, zabilježen i u samoj Bosni Srebrenoj 30-ih godina kada je u samostanu u Kraljevoj Sutjesci dvije godine boravio talijanski franjevac Filippo Antonio Belli. Njega je sa sobom onamo doveo apostolski vikar fra Rafo Barišić kao apostolskoga misionara. Takav je postupak izazvao veliko nezadovoljstvo franjevaca suprotstavljenih Barišiću. U tekstu, čije se autorstvo često pripisuje Franji Jukiću, Belli je opisan kao "trutina (...) osobito kisela kupusa i slanine željan Talianac". ${ }^{102}$ Prema jednome drugom izvješću, jedna poveća skupina je Belliju čak prijetila premlaćivanjem i smrću pa je ustrašen za vlastitu sigurnost molio Barišića da mu dopusti otputovati natrag u Italiju ${ }^{103}$ Ono što je za naslov-

100 Izvješće je objavljeno u: Dragutin Kamber, "Prilozi povijesti bosanskih franjevaca. Stanje župa i duša apostolskog vikarijata u Bosni srebreničko otomanskoj prema popisu izvršenom 1813.", u: Franjevački vjesnik, br. 12 (prosinac 1931.), str. 369-376; br. 1 (siječanj 1932.), str. 22-28; br. 2 (veljača 1932.), str. 57-59; br. 3 (ožujak 1932.), str. 83-88; br. 4 (travanj 1932.), str. 111121. Miletić ga je sastavio u Fojnici, 4. lipnja 1815.

101 O tome više: S. M. DžAJA, Katolici u Bosni i zapadnoj Hercegovini, str. 156-164.

102 Citirano prema: Josıp Matasović, Fojnička regesta, Sremski Karlovci, 1927., str. 314.

103 Usp. Arhiv franjevaČkog samostana u Kreševu (dalje: AFSK), B. Urudžbeni zapisnici, Kut. 15, Ur. Zap. 1, str. 10-11 (paginacija R. B.). Prema 
nu temu bitno, a što primjećuje i (ukoliko je doista on autorom) Jukić jest to što Belli, naravno, nije znao, a očito se nije ni potrudio naučiti hrvatski jezik, pa je bio neiskoristiv za ikakvu pastoralnu službu. Miletić kako ćemo vidjeti, na žalost, ne bilježi koju je točno službu spomenuti svećenik vršio, ni gdje je bio smješten, no opravdano je pretpostaviti da bi, da je potjecao negdje izvan bosanskoga prostora, to bilo posebno naznačeno i da bi vjerojatno njegova funkcija bila privremenoga karaktera i sigurno ne bi povlačila za sobom pitanje jurisdikcije. Uza svu šturost podataka, kao logičan nameće se zaključak da se spomenuti svećenik nalazio u Miletićevoj jurisdikcijskoj nadležnosti.

Imajući u vidu sve navedeno, jasno je da se kao najvjerojatnija pretpostavka nameće ona prema kojoj se iza te atribucije krije jedan od četvorice sekularnih klerika kojima je 1800. oduzeta stipendija. Opisano je kako u jednome slučaju (Nikolić) postoje snažne indicije, a u drugome (Vasiljević) konkretni dokazi za zaključak da se ti klerici nisu nikada vratili u svoj uži zavičaj. Od preostale dvojice ime jednoga, Luke Marijanovića izrijekom se spominje u kasnijim izvorima. Stanovitoga "Luku Marianovicha" u Fojnici, 25. kolovoza 1802., Mato Ivekić primio je u franjevački Treći red. ${ }^{104} \mathrm{Ne}$ navodeći druge primjere Džaja govori kako je primanje glagoljaša među trećorece bilo uobičajeno u ono vrijeme te na osnovi toga Marijanovića i atribuira kao jednoga od njih. Radi li se tu o bivšem sekularnom kleriku? Valja odmah napomenuti da spomenuta kombinacija imena i prezimena veoma vjerojatno nije bila rijetka i da nije isključeno da je, jednako kao i u slučaju brojnih franjevaca, postojalo i preklapanje između nekoga Luke Marijanovića koji je bio glagoljaš i nekoga koji je bio sekularnim klerikom.

Ratko Perić u svojoj studiji o popovima (svećenicima) glagoljašima njegovo mjesto rođenja smješta u Priluku kraj Livna, ali s određenom rezervom, budući da je čak i sam Marijanović za života svoje porijeklo navodio spominjući obližnja, ali ipak različita mjesta. ${ }^{105}$ Tako se,

jednoj bilješci na naslovnici vidljivo je kako je ovaj zapisnik nastao u Kraljevoj Sutjesci, a kasnije je premješten u Kreševo.

104 S. M. DžAja, Katolici u Bosni i zapadnoj Hercegovini, str. 157, bilj. 290.

105 Usp. Ratko Perić, Svećenici glagoljaši na području BiH: Trista godina djelovanja (1551.-1851.), Crkva na kamenu, Mostar, 2016., str. 290-294 gdje je autor prikupio brojne podatke o Marijanovićevu životu i osobito pastoralnoj djelatnosti. 
uz navedeno, spominju i Srđevići i Čuklić. U školskim izvješćima, nastalim tijekom njegova boravka u Zagrebu, kao mjesto rođenja beziznimno stoji Livno koje je regionalno određeno kao "Dalmatia Turcica". ${ }^{106}$ Perić datum rođenja određuje "oko 1770.", dok bi se prema izvješćima moglo raditi o periodu 1766. - 1768., no uzevši u obzir nepouzdanost njihovih datiranja, ova diskrepancija nije ništa neobično. Najupadljivije nepodudaranje između podataka koje prezentira Perić i onih koje je Marijanović očito sam o sebi pružao tijekom boravka u Zagrebu jest identitet oca. Doduše, Perić govori kako se u popisu katolika iz 1768. u Kablićima pokraj Livna spominje obitelj nekoga Andrije Marijanovića "s devetero odraslih i petero djece" za koju autor iznosi kako je opravdano pretpostaviti da iz nje potječe i "don Luka" iz čega ne proizlazi kako bi njegovim ocem morao nužno biti baš spomenuti Andrija. ${ }^{107} \mathrm{U}$ izvješćima je kao ime oca redovito ubilježeno Ivan (Joannes), a jednom se spominje i majčino ime Katarina (Catharina) što su nedvojbeno podatci koji mogu pomoći u nekim budućim analizama.

Uza sve navedene ograde, vjerojatnim se čini zaključak kako se radi o istoj osobi, odnosno da je glagoljaš don Luka Marijanović bio nekadašnji zagrebački đak. Valja se ovdje prisjetiti da je Marijanović u trenutku gubitka stipendije pohađao tek prvu godinu studija filozofije. Premda u nekim drugim slučajevima takav nedostatan kurikulum obrazovanja nije predstavljao prepreku za stupanje $u$ franjevački red i svećeničko ređenje, kao u slučaju Alovića, moguće je da Marijanović nije ni želio postati franjevcem pa se jednostavno pridružio glagoljašima. Uostalom, njihova je prisutnost bila izražena u kraju iz kojega je Marijanović i potjecao - Livnu.

S druge strane, opravdano je i postaviti pitanje je li Marijanović uopće bio glagoljašem? Naime, kako pokazuje i sam Perić, ovaj se svećenik prilikom vođenja matičnih knjiga koristio latinskim jezikom

106 Usp. npr. HR-DAZG-102, kut. 25623, br. 21. Cathalogus auditorum primae grammatices classis $1^{\text {mo }}$ semestri anni $1795^{\text {ti }}$ exhibitus. Marijanovićev boravak u Zagrebu poznat je također isključivo na osnovi školskih izvješća, odnosno u okvirima gradiva koje je polazio te uspjeha koji je ostvarivao. Uzme li se u obzir da je u Zagreb stigao još 1792. (usp. bilj. 17), očito je i on do 1795. polazio "normalku." Za razliku od ostalih klerika, spominjanih u ovom radu, podatci o njegovu mjestu rođenja, kao i imena roditelja uvijek su konzistentni. Nešto je drugačija situacija s godinama rođenja. O tome više u glavnom tekstu.

107 Usp. R. Perić, Svećenici glagoljaši, str. 290. 
što je neosporno pokazatelj njegova obrazovanja u Zagrebu, a ne u Priku kod Omiša gdje su se školovali glagoljaši. Džaja se osvrće na Miletićevo izvješće iz 1813. i navodi kako je taj "latinski svećenik" u stvarnosti također bio glagoljaš, ali koji je obavljao liturgiju prema latinskom obredniku. ${ }^{108}$ Zapravo, autor naizgled olako prelazi preko Miletićeva jasnog razlikovanja atribucija "sacerdos" i "presbyter" za koje se može pretpostaviti da je bilo dosljedno. ${ }^{109}$ Perić raspravlja o dopisu Kongregaciji za širenje vjere (Propagandi) iz 1824. gdje se Miletić ne baš biranim riječima izrazio o osmorici glagoljaša. ${ }^{110}$ Ostavljajući ovom prilikom po strani pitanje (ne)opravdanosti stavova koje je iznio apostolski vikar, valja se usmjeriti na terminologiju koju koristi. Jednako kao i u izvješću s njegove apostolske vizitacije 1813. i ovom ih prilikom naziva "presbyteri". Marijanovićeva imena ondje nema jer je preminuo 1818., a zapis o njegovoj smrti atribuira ga kao "sacerdos". ${ }^{111} S$ druge strane, jedno izostavljanje Marijanovićeva imena u vrijeme dok je bio živ kudikamo jače upada u oči, a do sada je prošlo potpuno nezapaženo. Radi se o molbi seoskih starješina "Ljubuškoga Mostara Duvna livna i Kuprisa i Rammae i sve ercego-

108 Usp. S. M. DžAJA, Katolici u Bosni i zapadnoj Hercegovini, str. 158, bilj. 293.

109 Neovisno o tome kakav je bio Marijanovićev crkveno-pravni položaj de jure, jasno je da je on (ili Zubčević!) de facto u odnosu prema franjevačkom kleru bio u poziciji identičnoj onoj glagoljaša, dakle gotovo bez ikakva institucionalnoga zaleđa iza sebe i bez mogućnosti da dobije ikakav drugačiji položaj osim ispomoći nekomu franjevačkom župniku. U takvome se kontekstu inzistiranje na razlici između "glagoljaša" i "latinskih svjetovnih svećenika" može doimati izlišnim. Imajući, na drugome kraju, u vidu prvotne intencije habsburške politike da se u Bosni etablira domaći kler, neovisan o franjevačkom, u sklopu kojih se planova glagoljaše nikada nije uzelo u obzir kao moguću lokalnu alternativu, jasno je da ova distinkcija ima određenu težinu. Istiskivanje Bosne Srebrene, odnosno Hercegovačke franjevačke provincije Uznesenja BDM iz nadležnosti nad župama započet će tek nakon dolaska Austro-Ugarske, odnosno kada i glagoljaši i latinski svećenik spornoga identiteta već budu davnom prošlosti pri čemu su - kako i ovaj rad jasno pokazuje - prvi iza sebe ostavili koliko-toliko trajnu uspomenu i predaju, dok je drugi do danas ostao potpuno zaboravljen i neprepoznat kao zanimljiv povijesni kuriozitet. Njegov konkretan odnos prema franjevcima Bosne Srebrene kao srodnima po latinskom obredu s jedne, odnosno glagoljašima kao bližima po statusu svjetovnih svećenika s druge strane, vjerojatno zbog nedostatka izvora nikada ne će moći biti u potpunosti rekonstruiran, ali upravo stoga njegov status treba biti jasno istaknut kao poseban.

110 Usp. R. PERIĆ, Svećenici glagoljaši, str. 76-77.

111 Isto, str. 294, bilj. 31. 
vine Turske" upućenoj 1808. Propagandi s ciljem da ova intervenira u korist nekolicine glagoljaša kojima je Grgo Ilijić priječio obavljanje svećeničke dužnosti. ${ }^{112}$ Marijanović je nedvojbeno cijeli svoj pastoralni vijek proveo djelujući u livanjskom (Vidoši) i kupreškom kraju. Zbog čega se onda i on ne bi našao na meti Ilijićevih nastojanja oko suzbijanja glagoljaške djelatnosti, nego je očito nesmetano vršio svoju službu? Zbog čega nije dao podršku ili se barem načelno solidarizirao sa šestoricom glagoljaša u čiju su korist seoske starješine uputile spomenutu intervenciju?

Ova pitanja, kao i neka druga, konkretno ono zbog čega se nije kao i Alović i Kordić pridružio Bosni Srebrenoj, u nedostatku izvora ostaju bez odgovora, pa stoga valja promotriti i scenarij prema kojemu je svjetovnim svećenikom kojeg 1813. spominje Miletić bio Filip Zubčević. U prilog ovoj tezi govori kako je bio dovoljno daleko dogurao sa studijem teologije, a da bi mu se stavljale ikakve zaprjeke za primanje svetih redova kao i to da postoje čvrste indicije kako je iz Zagreba otputovao natrag kući. Može se pretpostaviti da se preko Dalmacije najprije uputio u rodni kraj. Nakon toga je mogao na neki način stupiti u kontakt $s$ apostolskim vikarom Grgom Ilijićem te biti zaređen za svećenika. Potom je vjerojatno službovao kao kapelan na nekoj od župa. No, premda usporedba prema dosegnutoj razini studija između Marijanovića i Zubčevića nedvojbeno preteže u korist potonjeg što bi ga činilo uvjerljivijim kandidatom za ulogu prvog svjetovnog svećenika latinskoga obreda na prostoru otomanske Bosne u 19. st., njegovo ime se do sada nije pojavilo ni u jednome izvoru i jednostavno nedostaju ikakve potvrde da je nakon napuštanja Zagreba doista i stigao u svoj zavičaj. Osim već toliko iznesenih pretpostavki moraju se ostaviti otvorenima i one da je Zubčević napustio svećenički poziv bilo da se vratio u Hercegovinu, bilo da je svoju sudbinu potražio negdje drugdje, odnosno da je jednako kao i Vasiljević pastoralno djelovao na drugome mjestu, možda u Dalmaciji.

Buduća bi istraživanja sačuvanih matičnih knjiga iz bosansko-hercegovačkih župa u svakom slučaju trebala obratiti posebnu pažnju na pitanje identiteta ovoga svećenika. Ukoliko je to bio Luka Marija-

112 Hrvatski izvornik (u kojemu su imena Livna i Hercegovine ubilježene malim početnim slovom!) i onovremeni prijevod na talijanski kao priloge svom radu donosi: Ante ŠKegro, "Jedno biskupovo pismo i njegov usud", u: Bosna Franciscana - časopis Franjevačke teologije, god. XXII., br. 63, Sarajevo, 2014., str. 376-377. 
nović, postala bi upitnom dosadašnja verzija o njegovoj pripadnosti glagoljašima. Ako se pak radi o Filipu Zubčeviću, onda bi nedvojbeno bila riječ o prvome svjetovnom svećeniku pastoralno aktivnom $u$ otomanskoj Bosni rođenom ondje, koji nije bio glagoljaš.

\section{Zaključak}

Pokušaj da se školovanjem dvanaestorice klerika u Zagrebu stvore preduvjeti za etabliranje redovite dijecezanske strukture neovisne o Franjevačkoj provinciji Bosni Srebrenoj, u dugotrajnom previranju dviju crkvenih hijerarhija, redovničke i dijecezanske oko pitanja nadležnosti nad župama bosansko-hercegovačkoga prostora, predstavlja tek jednu epizodu koja je sve donedavno prolazila ispod radara historiografskoga interesa i istraživanja. Njezino djelovanje nije ispunilo predviđene ciljeve, a povijesno-političke okolnosti utjecale su i na to da zainteresirani čimbenici nakon samo desetak godina odustanu od daljnjih pokušaja provođenja ove ideje. Međutim, i tako privremen i veoma brzo prekriven povijesnim zaboravom i pogrješnim interpretacijama, taj je pokušaj ostavio posljedicu kudikamo duljeg i snažnijeg trajanja: zaklada Josipa II. bila je prenamijenjena za školovanje klerika Bosne Srebrene čime će više od 250 njezinih članova tijekom perioda od gotovo 5 desetljeća biti obuhvaćeno ovim procesom.

Dosege i posljedice ovako dugotrajnoga i kontinuiranoga procesa tek treba uočiti i adekvatno valorizirati, no pri tome se ne smije izgubiti iz vida kako dvanaest klerika predstavlja dvanaest pojedinačnih sudbina koje nije uvijek lako, često ni moguće, do kraja rekonstruirati. Među njima, nalaze se i trojica mladića iz Hercegovine čije je školovanje u glavnim crtama imalo sličan tijek, ali su im sudbine nakon toga veoma različite. Najpoznatijom bila je ona Jure Kordića koji će kao fra Petar vršiti brojne dužnosti u Bosni Srebrenoj, pa tako i onu provincijala. ${ }^{113}$ Upravo ta veza s franjevaštvom pokazuje dubinu njegove ukorijenjenosti u crkvenu prošlost bosansko-hercegovačkoga prostora i tamošnjih prilika jer je do nedavnih istraživanja najmanje poznatim dijelom Kordićeve biografije bilo upravo njegovo školovanje. Vjerojatno ne slučajno upravo zbog toga što nije bilo usmjereno ka stupanju u franjevački red, iako se ono u konačnici, na njegovu vlastitu inicijativu i odigralo.

113 Usp. bilj. 7. 
$\mathrm{Na}$ drugoj strani, analiza školskih putova preostalih klerika koji su ih dovršili otkriva još četvoricu koji su se nalazili na nekoj od školskih razina u trenutku kada je KUNV ukinuo njihovo stipendiranje kako bi dodijelio sredstva za uzdržavanje grupi franjevačkih klerika. Među njima su i dvojica Hercegovaca: Josip Vasiljević i Filip Zubčević. Analiza njihova školskoga puta gotovo da ne otkriva ništa neuobičajeno. Kako se moglo i očekivati, uzevši u obzir stanje obrazovnih institucija i mogućnosti njihova djelovanja u onovremenoj Bosni, klerici su u Zagreb došli s prilično mršavim predznanjem čak i iz onih predmeta iz kojih su dobivali određenu poduku, ponajprije latinskoga jezika. Dok su tu prepreku koliko-toliko uspješno nadvladavali, pa su gramatiku i humaniora uglavnom prolazili po redovitu planu i programu premda $s$ mršavim uspjehom, susret $s$ prirodnim predmetima tijekom studija filozofije kod obojice je doveo do višestrukoga ponavljanja gradiva pojedinih godina.

Na sve te poteškoće nadovezivale su se one psihološkoga i socijalnoga karaktera koje je iz današnje perspektive nemoguće u potpunosti procjenjivati. Na jednoj strani, zbog svih manjkavosti u predznanju, klerici su u gimnaziju stupali u već poodmakloj dobi u odnosu na ostale učenike. Dok je Vasiljević barem imao društvo nekolicine svojih zemljaka, Zubčević je velik dio gimnazije u razredu proveo sam. Naravno, nemoguće je znati koliki je utjecaj ovaj moment imao na njegov školski (ne)uspjeh, ali ga se sigurno ne smije zanemarivati. Stipendiste su pratile i druge poteškoće. Njihov smještaj u franjevačkom samostanu Provincije sv. Ladislava u Zagrebu nije se pokazao $\mathrm{s}(\mathrm{p})$ retnim rješenjem. Djelomično zbog nezadovoljstva franjevaca jednostranim nametanjem udomljavanja klerika, djelomično zbog oprjeke u mentalitetima, odnosi između dviju skupina su uvijek bili pomućeni i neminovno su vodili drastičnom prekidu. U trenutačno nepoznatom slijedu, ali najkasnije do sredine 90 -ih godina 18. st. svi su sekularni klerici, pa tako i Vasiljević i Zubčević morali potražiti privatan smještaj. Zbog nedostatnog iznosa stipendije često su morali trpjeti oskudicu i čak se zaduživati da bi imali krov nad glavom i te će ih nedaće pratiti do kraja njihova školskog puta.

Za sada je nemoguće utvrditi na koji su način promatrali svoju budućnost i koja je bila točka u kojoj su odlučili ostvariti svećenički ideal, no neosporna je činjenica da tijekom studija teologije možda nisu briljirali, ali nisu ni imali nekih izraženijih poteškoća u savladavanju gradiva. Dokidanjem stipendija i dovršetkom studija našli su se pred izazovom odabira daljnje sudbine. U nekom trenutku su 
se očito obojica bavili mišlju ostanka u Ugarskoj. Vasiljević je te planove i ostvario stupivši u svećenstvo Bosansko-srijemske biskupije u Đakovu gdje je službovao u tri župe, Berku, Račinovcima i Otoku gdje je 1837. i umro. Zubčević je s druge strane još tijekom gimnazije izborio svoje mjesto u povijesti kao vjerojatno jedan među prvima, ako ne i prvi polaznik lekcija iz mađarskoga jezika s bosansko-hercegovačkoga prostora. Međutim, njegova sudbina nakon dovršetka studija ostaje i dalje prilično nejasna. Postoji mogućnost da je upravo on "sacerdos saecularis" kojega na svome kanonskom pohodu 1813. bilježi apostolski vikar Miletić kao očito svjetovnoga svećenika kojega se jasno moglo razlikovati od glagoljaša označenih atribucijom "presbyteri", ali jednako legitimnim kandidatom za tu poziciju je i sekularni klerik iz Livna, Luka Marijanović kojega su dosadašnji istraživači možda prebrzo i olako proglasili glagoljašem. U prilog potonjoj verziji govori trenutačna zastupljenost u izvorima koji pokazuju Marijanovićevu aktivnu pastoralnu djelatnost, dok o Zubčeviću, kako je naglašeno, šute.

Trenutačno stanje istraženosti ne dopušta donošenje konačnoga zaključka o ovoj dvojici, ali utire jasan put ka zaokruživanju ove priče. Daljnjim istraživanjima bit će relativno lako rekonstruirati detalje o tome kako je tekao Vasiljevićev svećenički i župnički rad u Slavoniji i Srijemu. U slučaju Zubčevića to će ipak biti kudikamo teže jer osim brojnih pretpostavki trenutačno nema traga koji bi se mogao nedvosmisleno slijediti. Na svojevrsnoj mikrorazini sudbina trojice sekularnih klerika iz Hercegovine na prijelazu 18./19. st. kao da zrcali kasniju sudbinu svećenikâ s promatranoga područja: franjevaštvo (Kordić), pastoralnu djelatnost izvan užega zavičaja (Vasiljević), odnosno možebitan status svjetovnoga svećenika u samoj Hercegovini (Zubčević). Životopis svakoga od njih donosi poneki kuriozitet koji dodatno obogaćuje bogati mozaik crkvene povijesti hercegovačkoga prostora. 


\title{
Filip Zubcevic and Josip Vasiljevic - Secular Priests from Herzegovina Educated in Zagreb
}

\author{
Summary
}

Among the twelve clerics, who were sent by Augustin Botos Okic to Zagreb to get educated for secular priests, there were three candidates from Herzegovina. All of them successfully completed the schooling, after which their lives diverged. One of them, Jure Kordic, joined the Franciscan Province of Bosna Srebrena (Bosnia Argentina), and his education was the subject of earlier historiographic research. Beside him, Filip Zubcevic and Josip Vasiljevic passed all the preparations for priesthood in Zagreb.

The paper presents, as faithfully as possible, the reconstruction of their entire education from the probable preparations to entering the novitiate in Kresevo until the completion of theology studies in Zagreb. Thanks to archival materials, such as preserved school reports, we could analyse all gymnasium and academic levels they had attended, the courses they registered for, and the results they achieved, following thus all the challenges and obstacles they encountered. In the lower grades of gymnasium, their problem was the low pre-knowledge of the Latin language as well as the fact that they attended classes with teenage boys much younger than themselves. During their study of philosophy, they met with very demanding material from natural science courses and had to face the temporary failures and repetitions of study years. Finally, their theology studies were constantly in the shadow of uncertain future because they were threatened by cancellation of the scholarship due to changes in the goals and intentions of the fund that supported them.

Prior to the study of philosophy, they attended the classes separately. Zubcevic started the school earlier. From his high school days, the most interesting fact in his biography was that he had attended the course of Hungarian for two years as one of the first students after the Croatian Parliament's decision to introduce Hungarian as an optional subject in 1791 . On the other hand, some private data of his life remained rather vague. Thus, for the time being, it is possible to determine the place and date of his birth just approximately, while, unlike his colleagues, the name of neither of his parents was recorded. There was a wider range 
of information about Vasiljevic, for example, it was possible to determine that he was a native of Medjugorje, his parents' names were found, and thanks to his future life events, the exact date of his birth.

Their everyday life was full of problems with accommodation. In the early years, they lived in the Franciscan monastery in Zagreb, where Bosnian clergy quickly came into conflict with their hosts about disciplinary issues. The sources, for example, do not mention Zubcevic, but suggest that Vasiljevic's behaviour at that time was rather problematic. Finally, they left the monastery and found private accommodation, which later caused them various financial difficulties, the details of which, however, cannot be confirmed.

Until 1800, both successfully completed the study of theology after which their life paths diverged. Vasiljevic moved to the Diocese of Bosnia-Srijem and acted as a parish priest in Slavonia and Srijem. Zubcevic was last mentioned when he left Zagreb. It is possible that he eventually returned to Ottoman Bosnia and was pastorally active there as a secular priest of the Latin rite, in which capacity he was perhaps mentioned in 1813 by the apostolic vicar Augustin Miletic. The paper presents the arguments et pro et contra of this thesis, thus opening the way to future research.

Keywords: Filip Zubcevic; Josip Vasiljevic; Royal Academy; Bishop's lycée; Zagreb; Joseph II Foundation 